\title{
Southwestern Willow Flycatcher Breeding Site and Territory Summary - 2006
}

Scott L. Durst', Mark K. Sogge', Shay D. Stump², Sartor O. Williams ${ }^{3}$, Barbara E. Kus ${ }^{4}$, and Susan J. Sferra ${ }^{5}$.

Open File Report 2007-1391

U.S. Department of the Interior

U.S. Geological Survey



Photo by S. Sferra

\footnotetext{
${ }^{1}$ U.S. Geological Survey, Southwest Biological Science Center, Colorado Plateau Research Station, Flagstaff, AZ

${ }^{2}$ Arizona Game and Fish Department - Research Branch, Phoenix, AZ

${ }^{3}$ New Mexico Department of Game and Fish, Santa Fe, NM

${ }^{4}$ U.S. Geological Survey, Western Ecological Research Center, San Diego Field Station, San Diego, CA

${ }^{5}$ U.S. Bureau of Reclamation, Phoenix Area Office, Phoenix, AZ
} 


\section{U.S. Department of the Interior DIRK KEMPTHORNE, Secretary}

\section{U.S. Geological Survey \\ Mark D. Myers, Director}

U.S. Geological Survey, Reston, Virginia 2007

For product and ordering information:

World Wide Web: http://www.usgs.gov/pubprod

Telephone: 1-888-ASK-USGS

For more information on the USGS - the Federal source for science about the Earth, its natural and living resources, natural hazards, and the environment:

World Wide Web: http://www.usgs.gov

Telephone: 1-888-ASK-USGS

Suggested citation:

Durst, S.L., Sogge, M.K.,Stump, Shay D., Williams, Sartor O., Kus, Barbara E., and Sferra, Susan J. , 2007, Southwestern Willow Flycatcher Breeding Site and Territory Summary - 2006: USGS Open File Report 2007-1391. [http://pubs.usgs.gov/of/2007/1391/]

Any use of trade, product, or firm names is for descriptive purposes only and does not imply endorsement by the U.S. Government.

Although this report is in the public domain, permission must be secured from the individual copyright owners to reproduce any copyrighted material contained within this report. Cover photo by S. Sferra. 


\section{Contents}

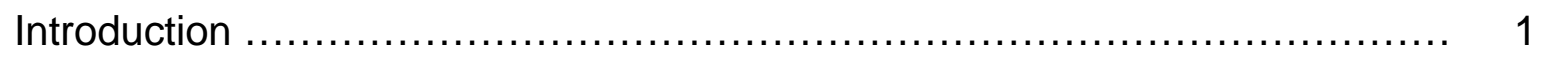

Changes in number of known territories over time ........................... 4

Number of sites over time: surveyed vs estimated........................................ 5

Number of territories over time: surveyed vs estimated................................ 6

Recency of survey data ................................................. 7

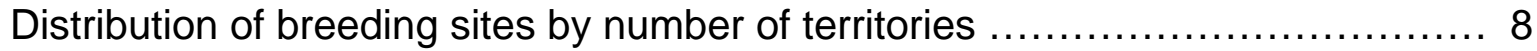

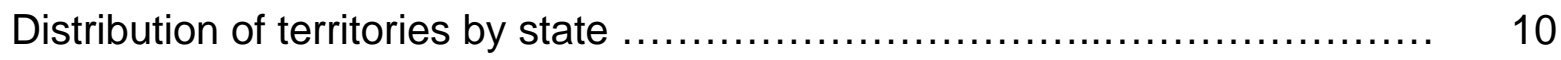

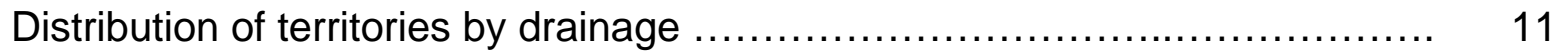

Distribution of territories by Recovery and Management Unit ................... 12

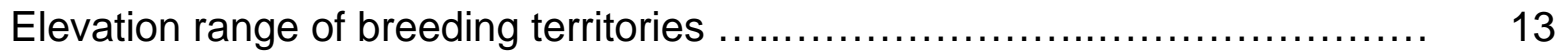

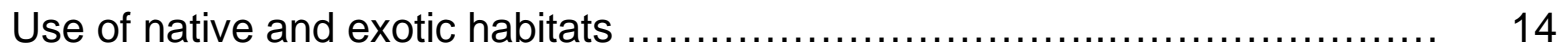

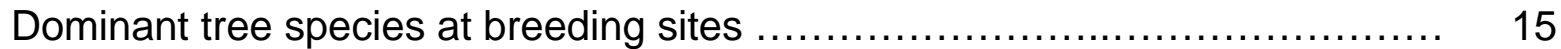

Administration/management of sites and territories ......................... 16

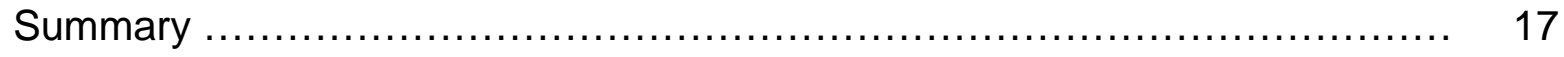

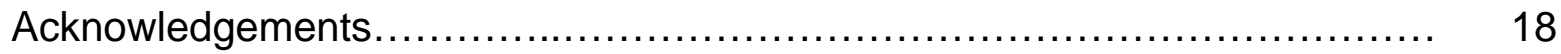

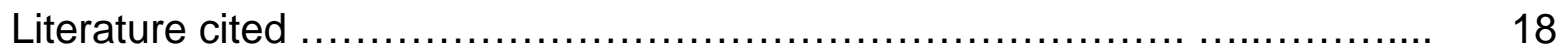

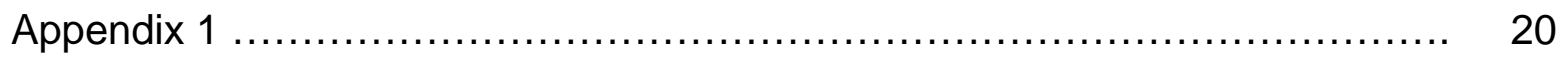

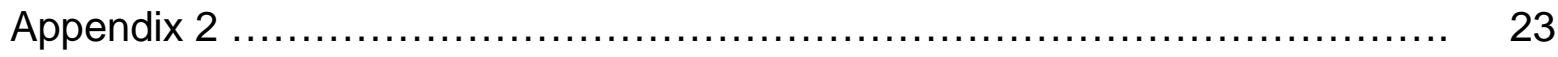




\title{
Southwestern Willow Flycatcher Breeding Site and Territory Summary - 2006
}

\author{
By Scott L. Durst, Mark K. Sogge, Shay D. Stump, Sartor O. Williams, Barbara E. Kus, and Susan
} J. Sferra.

U.S. Geological Survey Open File Report 2007-1391

\section{Introduction}

The Southwestern Willow Flycatcher (Empidonax traillii extimus) is an endangered bird that breeds only in dense riparian habitats in six southwestern states (southern California, extreme southern Nevada, southern Utah, southwestern Colorado, Arizona, and New Mexico). Since 1993, hundreds of Southwestern Willow Flycatcher surveys have been conducted each year, and many new flycatcher breeding sites located. This document synthesizes information on all known Southwestern Willow Flycatcher breeding sites.

This rangewide data synthesis was designed to meet these objectives:

1 - identify all known Southwestern Willow Flycatcher breeding sites, and

2 - assemble data on population size, location, habitat, and other information for all breeding sites, for as many years as possible, from 1993 through 2006.

This report provides data summaries in terms of the number of flycatcher sites and the number of territories. When interpreting and using this information, the following must be kept in mind:

A site is a location where one or more Willow Flycatchers establishes a territory. Sites with unpaired territorial males are considered breeding sites even if no nesting attempts were documented. A site is often a discrete patch of habitat; however, there is no standardized definition for site and its use varies among states. For example, five occupied habitat patches along a $10 \mathrm{~km}$ stretch of river might be considered five different sites in one state, but only a single site in another state. This lack of standardization makes comparisons based on "site" problematic. For this report, we deferred to statewide summary documents or to local managers and researchers when delineating a site for inclusion in the database. Due to differences in site definitions, one should not evaluate the relative importance of a geographic region (drainage, watershed, state, etc.) based simply on the number of flycatcher sites. 
$\boldsymbol{A}$ territory is an exclusive defended area within a breeding site. Although detailed monitoring studies have identified unpaired territorial males and/or polygynous males at some flycatcher breeding sites, for the purposes of this report a territory is roughly equivalent to a pair of flycatchers. In general the concept of territory is more similar among states and different investigators than is the term "site", thus it is a more robust unit to use for summaries and comparisons. However, keep in mind that the definition of a polygynous territory is not consistent among states; a male polygynously paired with two females would be considered one territory in some states and two territories in other states.

For each breeding site, we referred to reports or spoke directly with researchers and managers to gather information such as management entity/agency, location (state, drainage, elevation), gross habitat type (native, exotic, or mixed; dominant tree species), and number of flycatcher territories.

Synthesizing the information on more than 200 breeding sites is challenging because annual survey reporting requirements are not standardized rangewide, and the nature and degree of readily available information varied widely from state to state.

This is particularly true for areas such as California, where there are many flycatcher sites but surveyors are not required to submit standardized flycatcher survey forms. The lack of consistent reporting makes it difficult to determine precise survey locations, compare locations between years, standardize site names, and evaluate site-specific characteristics. It also introduces long delays in access to basic site and population information. However, California has instituted a state-wide database (coordinated by the USGS San Diego Field Station) that compiles data from an array of investigators; this database has greatly aided the compilation of data at the rangewide level. While Arizona, California, and New Mexico all compile state-wide survey summaries, Colorado, Nevada, and Utah do not have coordinated state-wide survey efforts and data for these state is compiled at the rangewide level.

This report includes all known flycatcher breeding sites reported between 1993 and 2006. The statistics included herein are based on survey data from the most recent year during which surveys were conducted, whether flycatchers were detected or not. Therefore, data from 158 sites that were not surveyed in 2006 are still included in the site and territory tallies if they had territorial flycatchers during one or more years since 1993. This report does not include data from sites where only migrant Willow Flycatchers were detected.

This report also includes sites that at some time since 1993 had territorial Southwestern Willow Flycatchers, but as of the most recent survey have zero territories. We considered these sites "extirpated" based on this definition but continue to include them in data summaries based on the most recent surveys conducted at these sites. Sites considered extirpated in one year may be recolonized by territorial flycatchers in subsequent years and we do not imply any regulatory or permanent designation in calling a site "extirpated". 
Additional Considerations in Using and Interpreting the Data in this Report: We used data from a wide variety of sources, and the amount of information and level of detail varied greatly among sites. Because survey methodology and effort varied among sites and/or between years, these summary data should be interpreted and used keeping this variation in mind. Following is a discussion of cautions to consider when using these data.

Subspecies status of each site: The sites entered into this database all fall within the geographic range of the southwestern subspecies (E.t. extimus), as defined by Unitt (1987), Browning (1993), Sogge et al. (1997), and USFWS (2002). Recent studies of flycatcher genetics (e.g., Paxton 2000) and song patterns (e.g., Sedgwick 2001) support a more southern range boundary for E.t. extimus than was used for the 1999 summary (Sogge et al. 2000). Future research may provide more insight into subspecies range boundaries; therefore, additional sites may eventually be removed from management as E.t. extimus, and/or new geographic areas and sites could be added. This should be considered when producing updates in future years, and when making rangewide comparisons among years.

Population estimates: Population estimates are just that - estimates. Their accuracy and precision vary with survey effort, survey intent, surveyor experience, habitat density, flycatcher behavior, and even background noise levels. The population estimates reported for a site are generally the minimum number of flycatchers that are likely present based on the overall survey results; i.e., if surveyors suspected 12 to 14 flycatchers, the lower (more conservative) number was used. Therefore, although estimates may be very accurate for some intensively surveyed sites, the overall statistics presented in this report should be recognized as approximate.

We sincerely thank the many people who generously provided information from the sites they were surveying and monitoring (see following sections listing data sources and contacts and acknowledgements). Every effort was made to locate and include all survey information for every known Southwestern Willow Flycatcher breeding site; however, due to delays in reporting for some sites, some 2006-season survey information may not be available until after this report is produced (November 2007). New 2006 survey information that is not included herein will be incorporated in future rangewide reports. 


\section{DATA SUMMARIES}

\section{Changes in the number of known territories over time}

Since 1993, extensive survey effort in Arizona, California, Colorado, Nevada, New Mexico, and Utah has greatly increased the number of known breeding sites and territories. From a 1993 estimate of 40 sites and 140 territories, we now have data for 284 sites and 1262 territories (Figure 1). This increase should NOT be interpreted entirely as a Southwestern Willow Flycatcher population increase. Rather, it is to a great extent a function of increased survey effort over time. Although population increases and decreases undoubtedly occur at some sites, movements of birds among sites and lack of standardized survey effort/reporting make it difficult to separate population trends from variances in survey effort. Determination of trends (positive or negative) can be made in only a few cases, and original data sources (e.g., reports, survey data sheets, etc.) must be consulted when trying to elucidate population trends.

FIGURE 1.

Estimated number of known breeding sites and territories, as of 2006. Numbers of sites and territories prior to $\mathbf{2 0 0 6}$ have been updated as new information has become available and may be different from past reports.

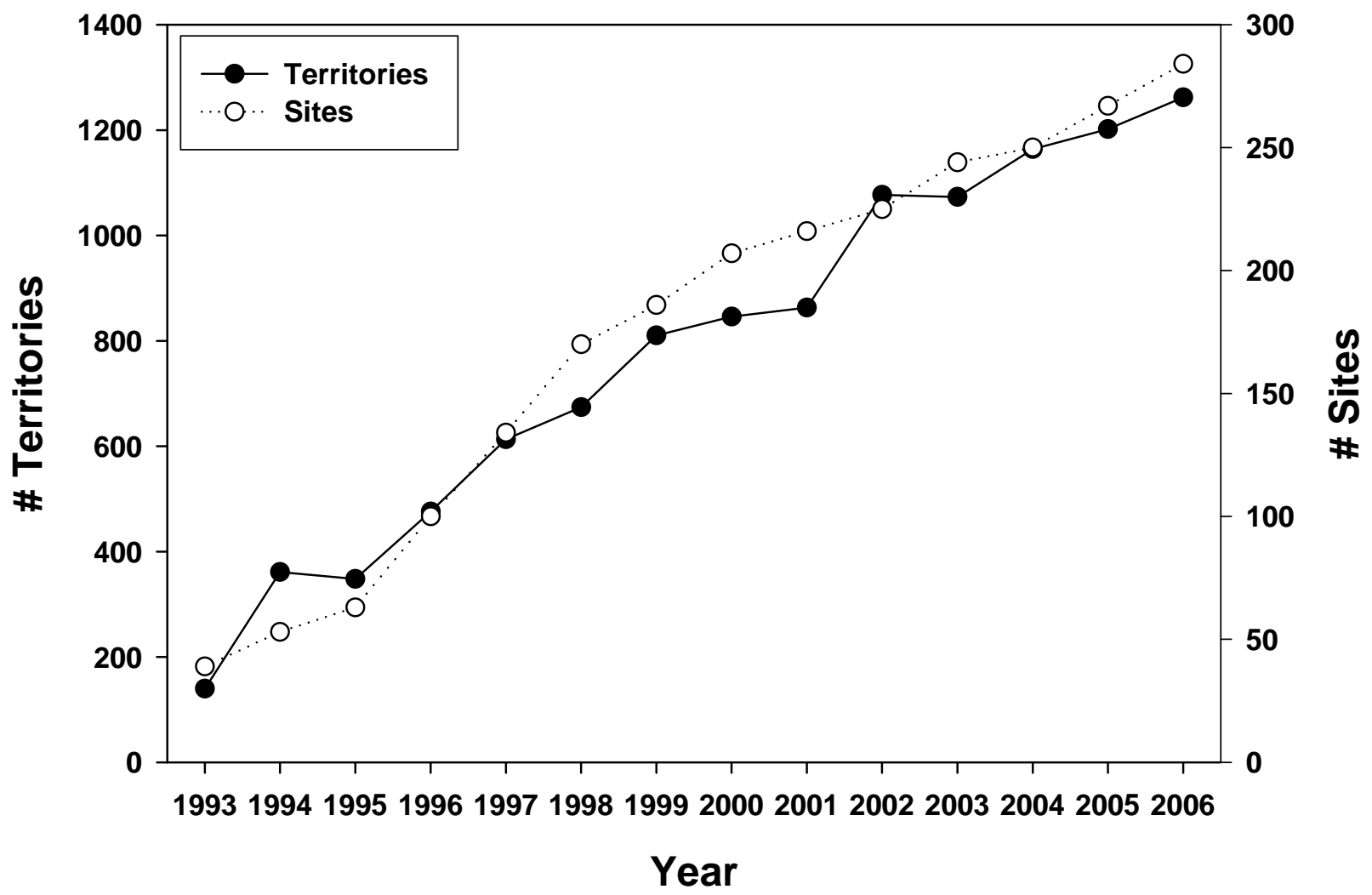




\section{Numbers of sites over time: surveyed vs estimated}

Not all of the 284 sites where Southwestern Willow Flycatcher territories have been discovered over the last 14 years are surveyed every year. However, our compilation includes all sites where flycatcher territories have been detected since 1993, including sites that were not surveyed in 2006 . Therefore the total estimated number of sites $(n=284)$ includes 126 that were surveyed in 2006, plus 158 that were last surveyed in 2005 or earlier. The number of sites actually surveyed each year increased from 1993 to 2001, but has been declining since then. This results in an increasing gap between the total number of estimated flycatcher sites and the number actually surveyed in the most recent year. See the section on Recency of Survey Data (below) and Appendix 1 for additional details.

\section{FIGURE 2.}

Number of estimated and surveyed breeding sites, as of 2006. Numbers of sites and territories prior to $\mathbf{2 0 0 6}$ have been updated as new information has become available and may be different from past reports.

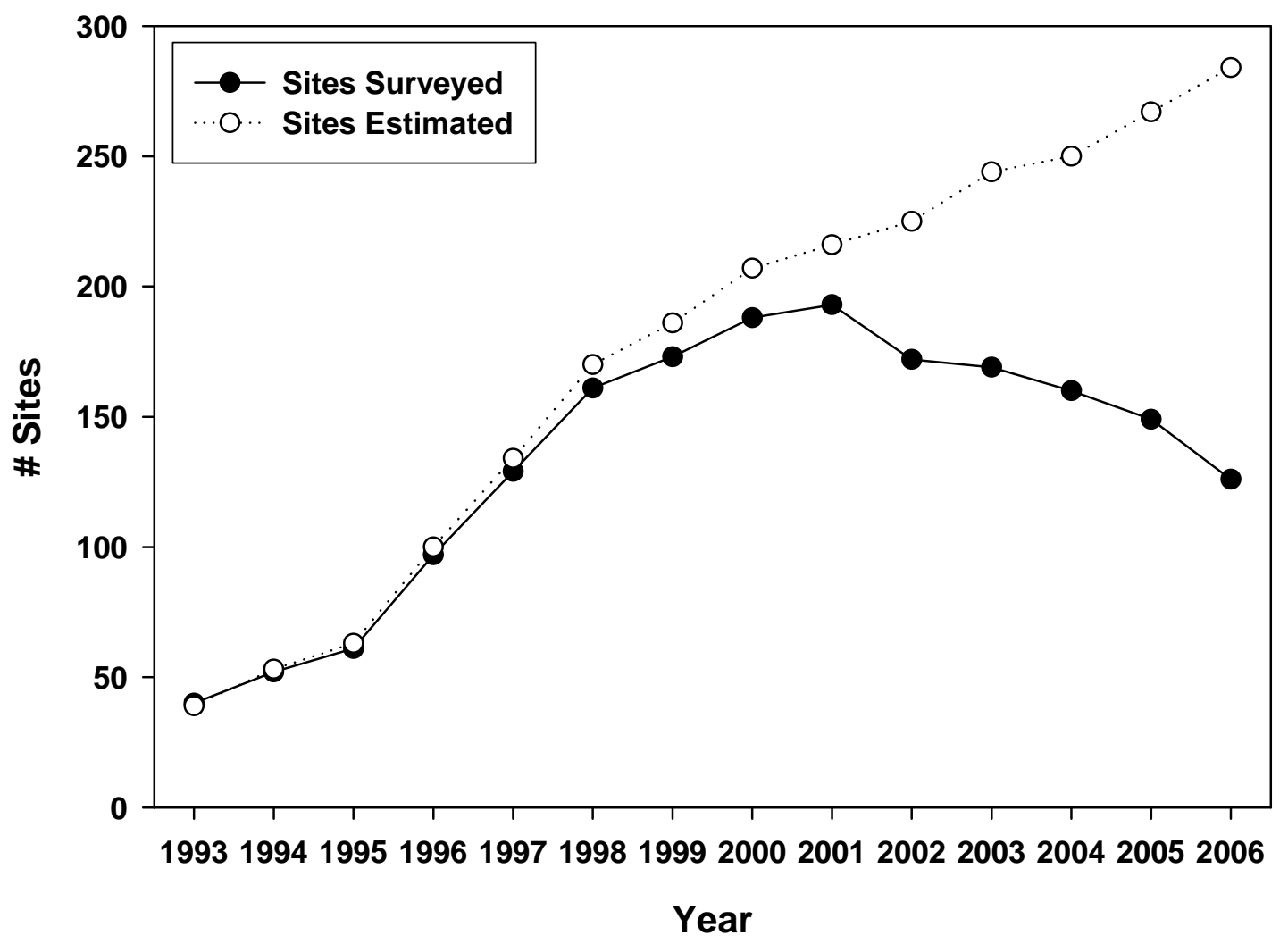




\section{Numbers of territories over time: surveyed vs estimated}

As previously noted, not all known Southwestern Willow Flycatcher breeding sites are surveyed every year. For sites that were not surveyed in 2006, we used the numbers reported in the most recent pre-2006 survey as an estimate of the number of territories currently at that site. Thus, for sites that were not surveyed in 2006, we continue to report the number of territories from the most recent survey year. In 2006, our estimated total number of territories (1262) includes 831 detected in 2006-season surveys, plus 431 territories from sites that were last surveyed in 2005 or before (Figure 3 ). As with site estimates, the trend over the last several years is for an increasing gap between the number of territories known via recent surveys and the total number estimated. See the section on Recency of Survey Data (below) and Appendix 1 for additional details.

\section{FIGURE 3.}

Number of estimated and surveyed territories, as of 2006. Numbers of sites and territories prior to 2006 have been updated as new information has become available and may be different from past reports.

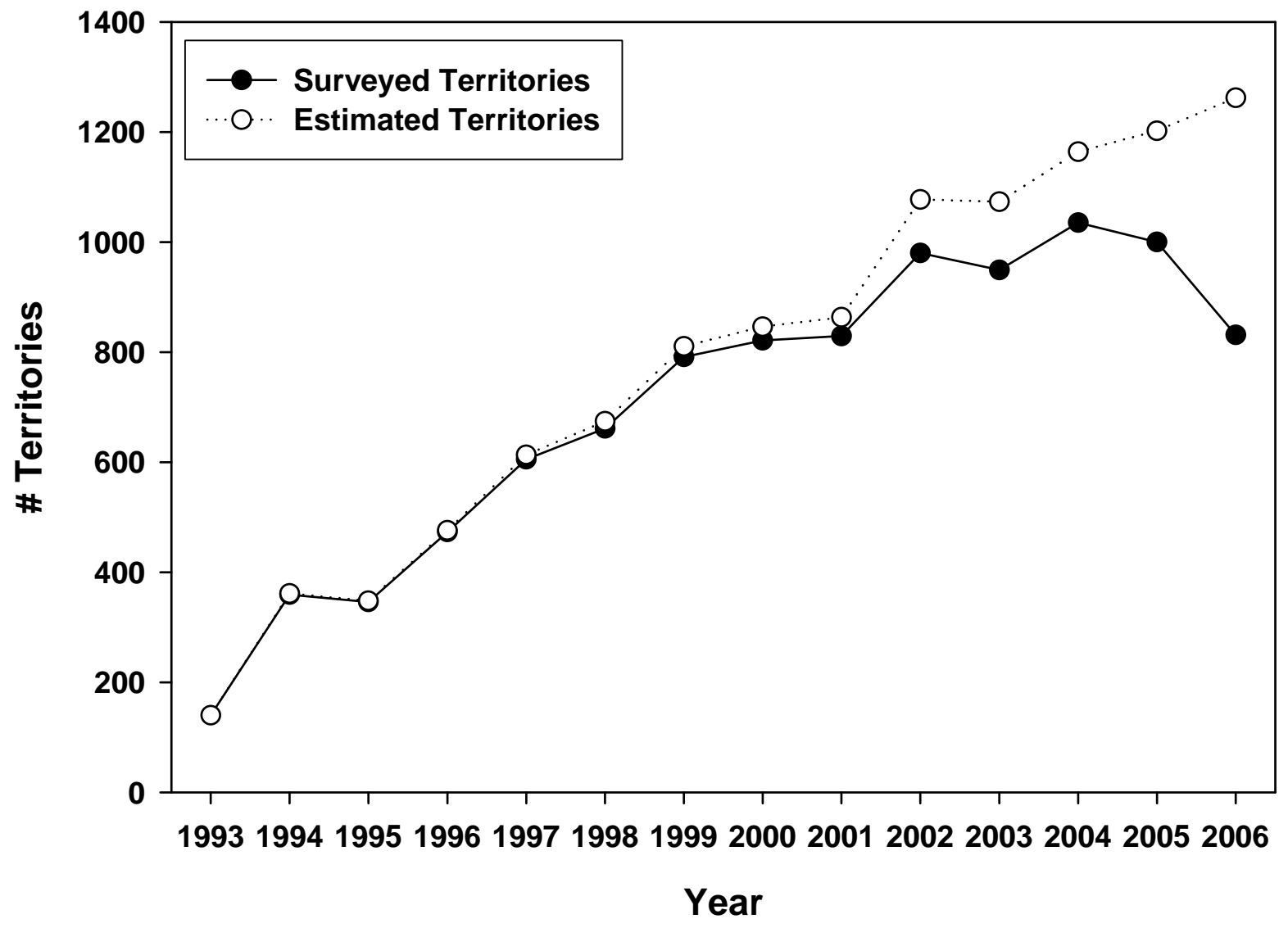




\section{$\underline{\text { Recency of survey data }}$}

As previously indicated, the information used in this report is based on the most recent available survey data for each site. However, not all sites are surveyed every year. Of the 284 sites where Southwestern Willow Flycatchers have occurred since 1993, only 126 sites were surveyed in 2006. Although our estimates for some sites are based on older survey data, over $68 \%$ of known sites have been surveyed since 2004 , and sites surveyed since 2004 account for almost $90 \%$ of the rangewide estimated number of flycatcher territories. Thus, the information used for most of the statistics reported herein is quite recent. All data presented in this report are based on the most recent survey available for a given site. For 126 sites. the data are from surveys conducted in 2006; however, for 158 sites the most recent data were collected prior to 2006.

Table 1. Most recent year of survey data for sites and territories included in this report, as of 2006.

\begin{tabular}{|c|c|c|c|c|}
\hline Year & \# Sites & $\begin{array}{c}\text { \% Total Sites } \\
(\mathbf{n}=\mathbf{2 8 4})\end{array}$ & \# Territories & $\begin{array}{c}\text { \% Total Territories } \\
(\mathbf{n}=\mathbf{1 2 6 2})\end{array}$ \\
\hline 1993 & 1 & 0.4 & 2 & 0.2 \\
\hline 1994 & 1 & 0.4 & 0 & 0.0 \\
\hline 1995 & 1 & 0.4 & 1 & 0.1 \\
\hline 1996 & 2 & 0.7 & 5 & 0.4 \\
\hline 1997 & 4 & 1.4 & 5 & 0.4 \\
\hline 1998 & 4 & 1.4 & 6 & 0.5 \\
\hline 1999 & 6 & 2.1 & 6 & 0.5 \\
\hline 2000 & 4 & 1.4 & 9 & 0.7 \\
\hline 2001 & 30 & 10.6 & 63 & 5.0 \\
\hline 2002 & 22 & 7.7 & 27 & 2.1 \\
\hline 2003 & 15 & 5.3 & 5 & 0.4 \\
\hline 2004 & 28 & 9.9 & 73 & 5.8 \\
\hline 2005 & 40 & 14.1 & 229 & 18.1 \\
\hline 2006 & 126 & 44.4 & 831 & 65.8 \\
\hline
\end{tabular}




\section{Distribution of breeding sites by number of territories}

Most Southwestern Willow Flycatcher breeding sites are small, both in terms of the number of territories (hosting five or fewer territories: Figure 4) and habitat patch size. Willow Flycatcher territories have disappeared from 135 of the 284 sites tracked since 1993 and as of the most recent survey do not have any territories (See Appendix 2 for a list of extirpated sites). All but two of these sites where flycatcher territories are no longer detected were composed of five or fewer territories. The two exceptions Colorado River inflow to Lake Mead, and PZ Ranch on the San Pedro River - were larger sites where habitat was destroyed by flooding and fire, respectively. Additionally there have been incidences of fire and flooding that did not result in the total loss of flycatcher breeding habitats. There were fires during the 2004 and 2005 breeding seasons in Arizona at the Gila River Kearney Sewage Ponds and San Pedro River Dudleyville Crossing sites, respectively, that may have reduced the amount of suitable breeding habitat for flycatchers at these sites. The inundation of Roosevelt Lake and Horseshoe Reservoir in Arizona prior to the 2005 breeding season dramatically reduced the available riparian habitat at some sites. The long-term impact of fire and flooding at these breeding sites is unknown and should be examined through continued survey efforts.

Figure 4.

Number of territories at Willow Flycatcher Breeding Sites, as of 2006.

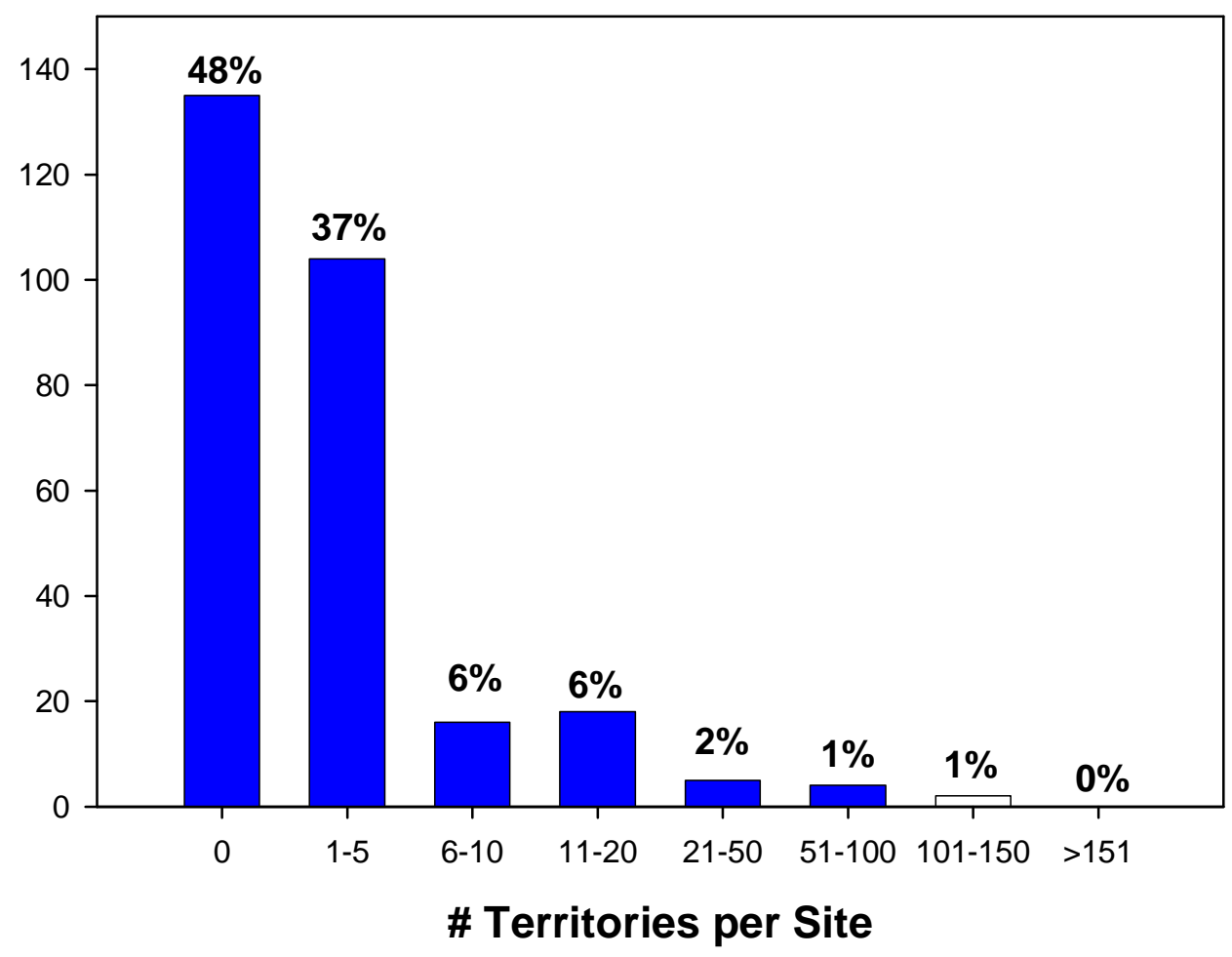


Not all birds at the sites where flycatcher territories are no longer detected necessarily died - some of these birds moved to other sites where they attempted to establish breeding territories. We know this is the case for banded flycatchers that moved from the Verde River Tuzigoot Bridge and PZ Ranch to other sites (Paxton and Sogge 1996, Paxton et al. 1997, Netter et al. 1998), plus numerous movements following the inundation of Roosevelt Lake (Causey et al. 2005). Some of these sites may eventually cycle back into occupancy by breeding flycatchers due to a change in habitat quality, an increase in number of nearby territories, or other unknown or undetected factors. There have been 45 sites that have been recolonized after at least one year of zero territorial flycatchers detections indicating that currently extirpated sites may develop suitable habitat in the future. Some of these sites have repeatedly cycled between occupied and unoccupied status and some currently have territories while others do not.

If we look again at the size distribution of breeding sites and exclude the sites where territories are no longer detected, the picture remains much the same - the vast majority of sites (104 of 149; 70\%) have five or fewer territories. Because most of the 135 sites where birds are no longer detected had very small populations (usually only one or two territories), their loss does not greatly affect the overall rangewide territory estimates, nor many of the territory statistics that we have reported herein. 


\section{Distribution of territories by state}

Arizona, New Mexico, and California account for the greatest number of known Southwestern Willow Flycatcher sites and territories (Table 2). Nevada, Colorado, and Utah account for about $12 \%$ of territories, primarily because these states have few known Willow Flycatcher breeding sites occurring far enough south to fall within the range of E.t. extimus. Texas is absent from this table because there were no survey data or other records to shed light on current status and distribution within the state. For a revised version of Table 2 that includes updated estimated and surveyed numbers of sites and territories by year and state see Appendix 1.

Table 2. Number of Southwestern Willow Flycatcher breeding sites and territories by state, as of 2006.

\begin{tabular}{|c|c|c|c|c|}
\hline State & \# Sites & \% of Total Sites & \# Territories & \% of Total Territories \\
\hline AZ & 123 & 43.3 & 482 & 38.2 \\
\hline CA & 96 & 33.8 & 190 & 15.1 \\
\hline CO & 11 & 3.9 & 58 & 4.6 \\
\hline NM & 38 & 13.4 & 443 & 35.1 \\
\hline NV & 13 & 4.6 & 82 & 6.5 \\
\hline UT & 3 & 1.1 & 7 & 0.6 \\
\hline TOTAL & 284 & & 1262 & \\
\hline
\end{tabular}




\section{Distribution of territories by drainage}

In general we have designated a drainage name to serve as a functional unit, rather than a defined hydrological unit, as a means to summarize site and territory information. More flycatcher territories are found along the Gila River than any other major drainage (Table 3); one of the largest known populations (in the Cliff-Gila Valley, NM) contributes many of the territories within this drainage. Elsewhere in New Mexico, and in southwest Colorado, most territories are along the Rio Grande. The primary flycatcher drainages in California are the Kern, Owen's, San Luis Rey, Santa Ana, and Santa Margarita rivers. In Arizona, most flycatchers are found along the Gila, San Pedro, and Salt River drainages. The Virgin River drainage supports the majority of flycatchers in Utah. The Virgin River and the Pahranagat River support most of the flycatchers in Nevada. Sites along the Colorado River are in Arizona, California, and Utah. The scale of all drainages in the rangewide summary is not equivalent and the drainage naming convention is specific to a particular watershed.

Table 3. The number of Southwestern Willow Flycatcher breeding sites and territories by major river drainage (drainages with $>1 \%$ of total flycatcher territories), as of the 2006 breeding season.

\begin{tabular}{|c|c|c|c|c|}
\hline Drainage & \# Sites & \% of Total Sites & \# Territories & \% of Total Territories \\
\hline Big Sandy River & 2 & 0.7 & 27 & 2.1 \\
\hline Bill Williams River & 6 & 2.1 & 14 & 1.1 \\
\hline Canadian River & 6 & 2.1 & 15 & 1.2 \\
\hline Colorado River & 41 & 14.4 & 27 & 2.1 \\
\hline Gila River & 49 & 17.3 & 326 & 1.3 \\
\hline Kern River & 2 & 0.7 & 16 & 2.2 \\
\hline Owen's River & 5 & 1.8 & 28 & 2.9 \\
\hline Pahranagat River & 4 & 1.4 & 36 & 4.4 \\
\hline Rio Grande & 25 & 8.8 & 263 & 4.7 \\
\hline Salt River & 6 & 2.1 & 56 & 12.4 \\
\hline San Luis Rey River & 9 & 3.2 & 59 & 2.6 \\
\hline San Pedro River & 19 & 6.7 & 157 & 1.7 \\
\hline Santa Ana River & 30 & 10.6 & 33 & 4.8 \\
\hline Santa Margarita River & 3 & 1.1 & 22 & 4.4 \\
\hline Tonto Creek & 1 & 0.4 & 61 & 4.2 \\
\hline Verde River & 6 & 2.1 & 18 & \\
\hline Virgin River & 8 & 2.8 & 51 & 53 \\
\hline All others* & 62 & 21.8 & 1262 & \\
\hline Total & 284 & & & \\
\hline
\end{tabular}

*All others includes drainages that had $<1 \%$ of total territories: Agua Fria River, Agua Hedionda, Amargosa River, Chama River, Hassayampa River, Las Flores Creek, Little Colorado River, Meadow Valley Wash, Mimbres River, Mojave River, San Diego Creek, San Diego River, San Dieguito River, San Felipe Creek, San Francisco River, San Gabriel River, San Juan Creek, San Juan River, San Mateo Creek, Santa Clara River, Santa Cruz River, Santa Maria River, Santa Ynez River, Sulphur Creek, Sweetwater River, Temecula Creek 


\section{Distribution of territories by Recovery and Management Unit}

We tallied the number of breeding sites and territories by Recovery Unit and Management Unit (Table 4), as defined in the Southwestern Willow Flycatcher Recovery Plan (USFWS 2002). Note that in some Management Units, the number of territories is less than the number of sites; this occurs where Management Units include primarily small sites, one or more of which no longer contains territorial flycatchers as of the most recent survey (i.e., "extirpated" sites; see Appendix 2).

Table 4. The currently known number of flycatcher breeding sites, territories (as of 2006 data) and number of territories necessary for recovery criteria, by Recovery Unit and Management Unit.

\begin{tabular}{|c|c|c|c|c|}
\hline Recovery Unit & Management Unit & \# of Sites & \# of Territories & Recovery Criteria \\
\hline \multirow{6}{*}{ Basin and Mojave } & Owens & 5 & 28 & 50 \\
\hline & Kern & 2 & 16 & 75 \\
\hline & Amargosa & 2 & 2 & 25 \\
\hline & Mojave & 7 & 4 & 25 \\
\hline & Salton & 1 & 4 & 25 \\
\hline & TOTAL & 17 & 54 & 200 \\
\hline \multirow[t]{5}{*}{ Coastal California } & Santa Ynez & 4 & 7 & 75 \\
\hline & Santa Clara & 12 & 8 & 25 \\
\hline & Santa Ana & 33 & 33 & 50 \\
\hline & San Diego & 24 & 88 & 125 \\
\hline & TOTAL & 73 & 136 & 275 \\
\hline \multirow[t]{8}{*}{ Gila } & Verde & 6 & 18 & 50 \\
\hline & Hassayampa - Agua Fria & 2 & 3 & 25 \\
\hline & Roosevelt & 7 & 117 & 50 \\
\hline & San Francisco & 2 & 3 & 25 \\
\hline & Upper Gila & 21 & 287 & 325 \\
\hline & Gila - San Pedro & 46 & 196 & 150 \\
\hline & Santa Cruz & 1 & 0 & 25 \\
\hline & TOTAL & 85 & 624 & 625 \\
\hline \multirow[t]{8}{*}{ Lower Colorado } & Pahranagat & 6 & 44 & 50 \\
\hline & Virgin & 7 & 43 & 100 \\
\hline & Little Colorado & 5 & 9 & 50 \\
\hline & Middle Colorado & 20 & 9 & 25 \\
\hline & Hoover - Parker & 6 & 14 & 50 \\
\hline & Bill Williams & 9 & 41 & 100 \\
\hline & Parker - Southern. Intl Boundary & 16 & 4 & 150 \\
\hline & TOTAL & 70 & 164 & 525 \\
\hline \multirow[t]{5}{*}{ Rio Grande } & San Luis Valley & 7 & 54 & 50 \\
\hline & Upper Rio Grande & 16 & 34 & 75 \\
\hline & Middle Rio Grande & 8 & 185 & 100 \\
\hline & Lower Rio Grande & 3 & 7 & 25 \\
\hline & TOTAL & 34 & 280 & 250 \\
\hline \multirow{3}{*}{$\begin{array}{l}\text { Upper Colorado } \\
\text { River }\end{array}$} & San Juan & 5 & 4 & 25 \\
\hline & Powell & 0 & 0 & 25 \\
\hline & TOTAL & 5 & 4 & 50 \\
\hline GRAND TOTAL & & 284 & 1262 & 1950 \\
\hline
\end{tabular}




\section{Elevation range of breeding territories}

The Southwestern Willow Flycatcher is distributed over a wide elevation range. The majority of sites occur between 0 and $1000 \mathrm{~m}$ elevation (Figure 5a). Most territories are found between 0 and $1600 \mathrm{~m}$ (Figure 5b), with "spikes" at 601-800 m (the Gila/San Pedro River confluence and Roosevelt Lake in AZ) and 1401-1600 m (the Cliff-Gila Valley in NM). Although relatively few territories are known to occur above $2000 \mathrm{~m}$ elevation, Willow Flycatchers breed at three sites that are above $2500 \mathrm{~m}$.

Figure 5.

Figure 5a. The percentage of flycatcher breeding sites located at different elevations, as of $2006(200=0-200 \mathrm{~m}, 400=201-400 \mathrm{~m}$, etc. $)$.

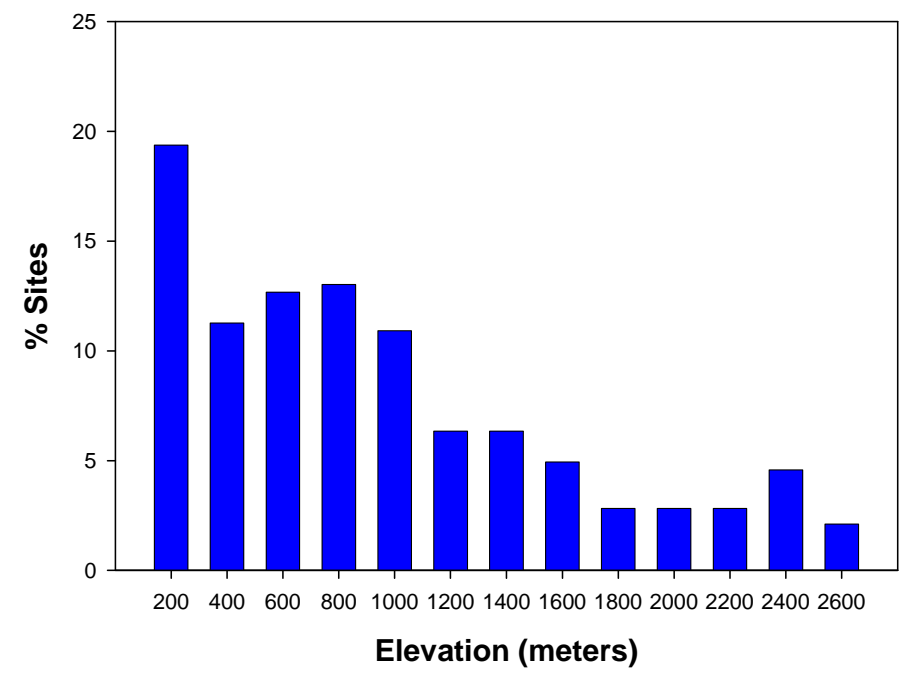

Figure 5b. The percentage of flycatcher territories occurring at differing elevations, as of $2006(200=0-200 \mathrm{~m}, 400=201-400 \mathrm{~m}$, etc.).

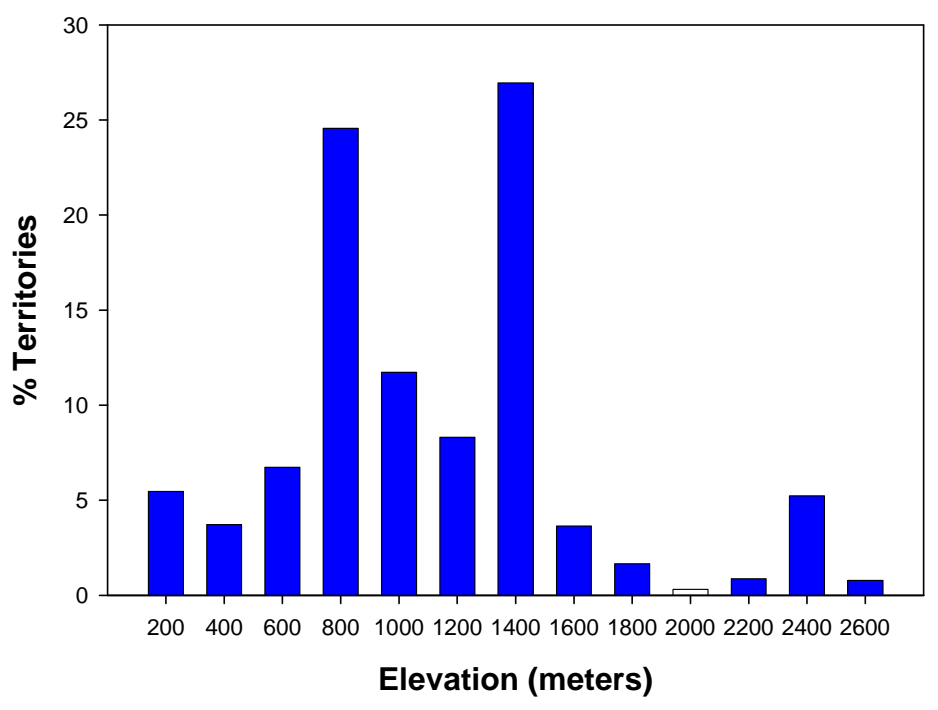




\section{Use of native and exotic habitats}

Most flycatcher breeding sites are comprised of spatially complex habitat mosaics, often including both exotic and native vegetation. Within a site territories are frequently clumped and/or distributed near the patch edge. Thus, the vegetative composition of individual territories may differ from the overall composition of the patch. However, depending on the time in the breeding season and the breeding status of an individual, flycatchers may move extensively within a patch, travel between patches, or exploit resources outside of a breeding patch (Cardinal et al. 2005, 2006). Therefore an area much larger than a territory and possibly much larger than a patch may be important to flycatcher breeding success and persistence at a particular site. This concept is supported by recent habitat modeling (Hatten and Paradick 2003, Paxton et al. 2007).

Detailed territory-based habitat measurements are lacking for the majority of Southwestern Willow Flycatcher breeding sites, yet we attempted to broadly characterize the use of native and exotic habitats. To do so, we classified the habitat at each site into one of four broad categories, based on the overall species composition of the tree/shrub layer(s) of the site. The categories were:

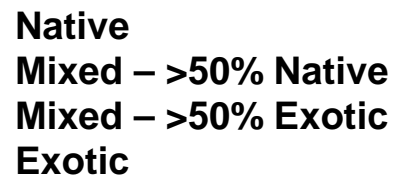

(>90\% native vegetation)

(50-90\% native vegetation)

(50-90\% exotic vegetation)

(>90\% exotic vegetation)

Habitat patches comprised of native vegetation account for less than half $(43 \%)$ of the known flycatcher territories (Figure 6 ). Although only $6 \%$ of territories occur at exotic sites, another $50 \%$ are located within sites where the habitat includes native/exotic mixtures. In many of these cases, exotics are contributing significantly to the habitat structure by providing the dense lower-strata vegetation that flycatchers prefer.

Figure 6.

Percentage of flycatcher territories occurring within breeding sites of differing compositions of native and exotic vegetation, as of the 2006 breeding season.

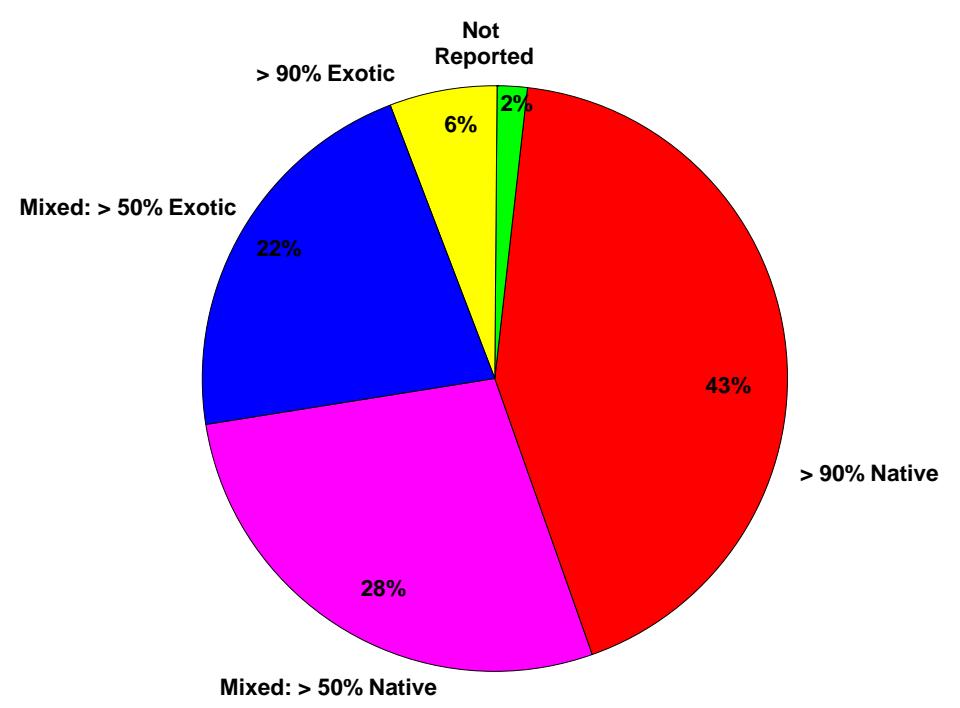




\section{Dominant tree species at breeding sites}

Similar to classifying breeding territory habitat based on patch-level characteristics, the dominant tree species may differ between a patch and an individual territory within that patch. Generally, detailed territory-based habitat measurements are lacking for the majority of Southwestern Willow Flycatcher breeding sites. Despite this limitation, it is useful to characterize the dominant tree species within known flycatcher breeding sites.

To characterize the degree to which flycatchers breed in habitats dominated by particular tree species, we tallied the number of territories occurring in breeding sites dominated by particular tree species. Over half (55\%) of territories are found at sites where willow (Salix spp) is the dominant tree species (Figure 7). Saltcedar (Tamarix spp.) predominates at sites that account for $27 \%$ of territories and $12 \%$ are in patches where boxelder (Acer negundo) is the most common habitat component. Taken together, sites dominated by all other tree species account for only about $5 \%$ of territories.

The large percentage of territories located in boxelder dominated habitats might suggest that boxelder sites are widely used across the Southwestern Willow Flycatcher's range. However, boxelder dominated breeding habitats occur only in the Cliff-Gila Valley, New Mexico (Stoleson and Finch 2003).

Figure 7.

Percentage of flycatcher territories occurring within breeding sites dominated by particular tree species, as of the 2006 breeding season.

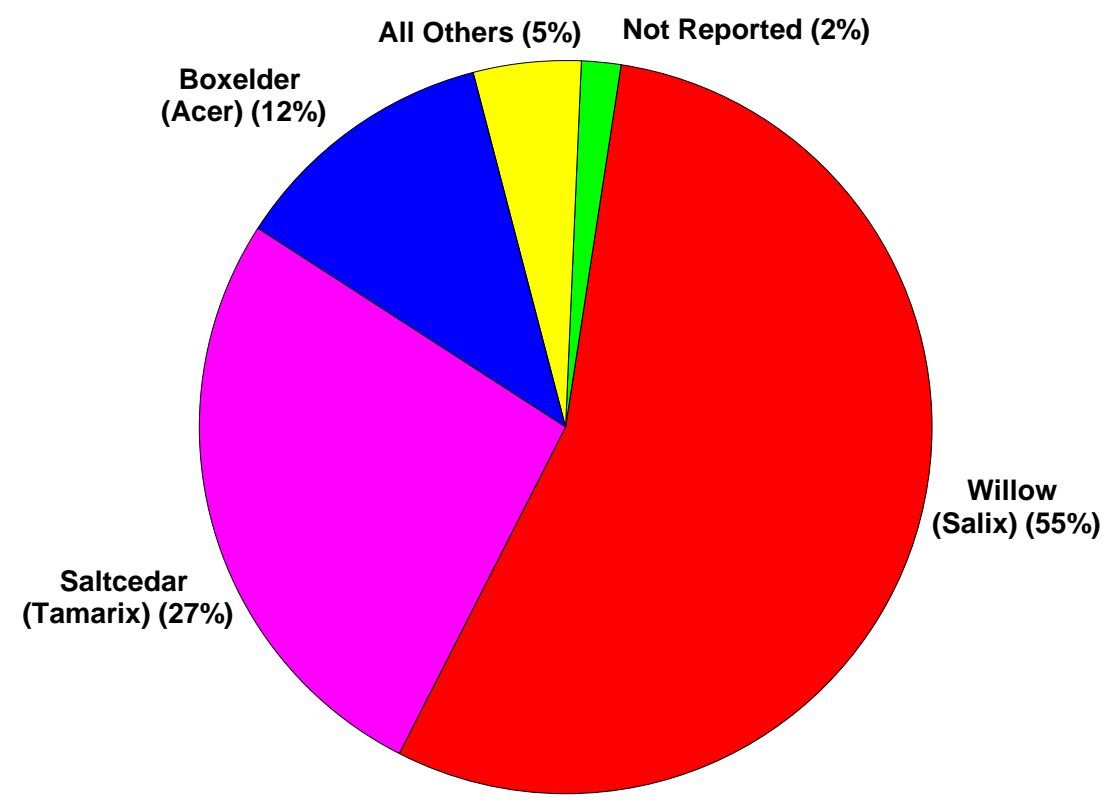




\section{Administration/management of sites and territories}

One factor important in conservation and recovery planning is the nature of ownership or administration of a site - e.g., whether management of the site is the responsibility of private landowners, the government, or some other entity. We examined this in two ways - first by site, then by territory.

By Site (Figure 8a): Forty-four percent of known breeding sites are under federal government administration, $28 \%$ are on privately owned lands, state/local/municipal governments account for another $13 \%$ of sites, and $5 \%$ are administered by Native American tribes.

By Territory (Figure 8b): Federal lands account for $53 \%$ of flycatcher territories, and private for $36 \%$. This underscores the importance of working with private landowners as flycatcher conservation and recovery efforts proceed. Roughly a third (32\%) of the flycatcher territories found on privately owned lands are in the Cliff-Gila Valley, New Mexico.

\section{Figure 8}

Figure 8a. Percentage of flycatcher breeding sites found under different land ownership, as of the 2006 breeding season.

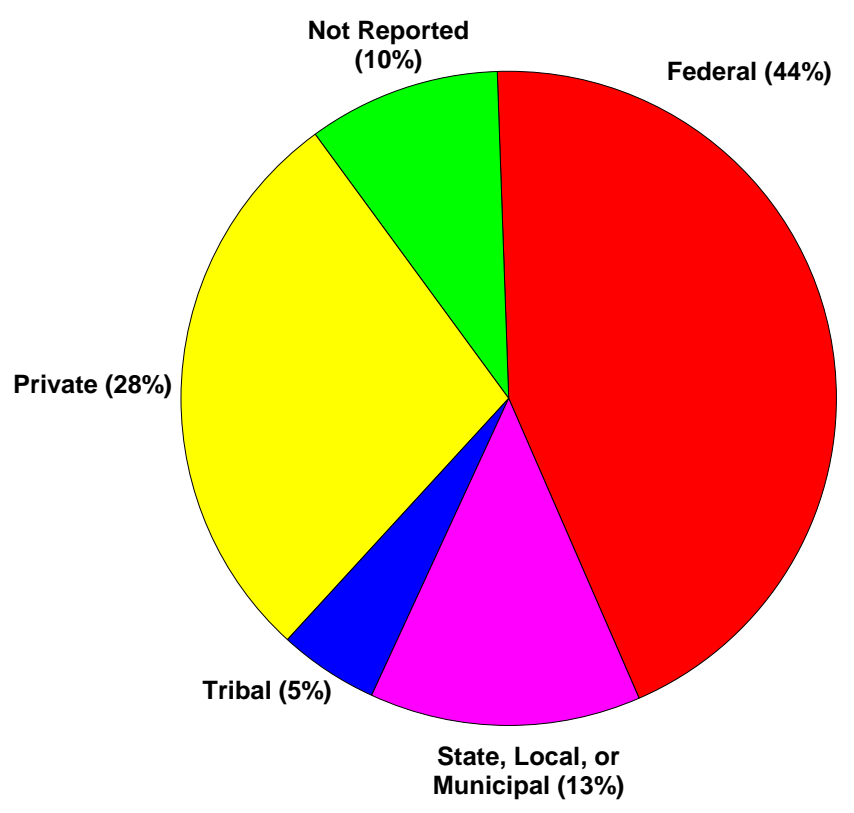

Figure 8b. Percentage of flycatcher territories found under different land ownership, as of the 2006 breeding season.

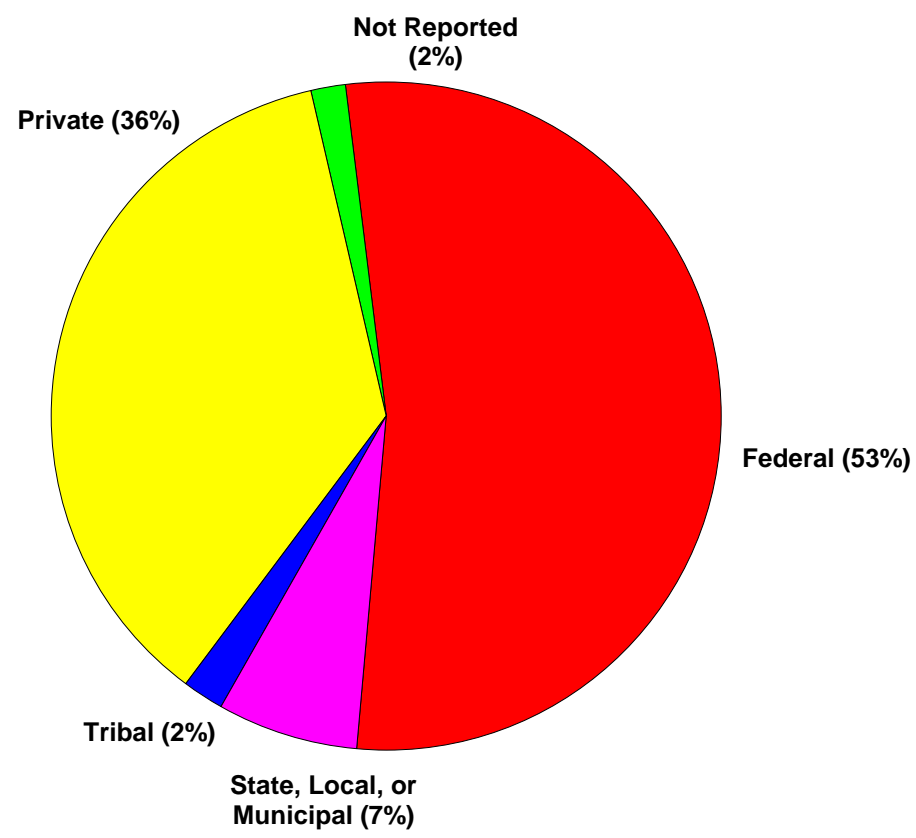




\section{SUMMARY: 2006}

- We have learned of many new breeding sites and territories since the early 1990 s as a result of extensive survey efforts throughout the Southwest. In 1993, there were only 140 known territories distributed among 40 breeding sites. The current estimate (as of 2006) is 1262 territories located among 284 sites (but remember the earlier caution about lack of standard definition for "site").

- Not all of the 284 known sites are surveyed every year. The total estimated number of known territories (1262) is based on the most recent survey at all sites and does not reflect sites that were actually surveyed in a given year. At 126 sites surveyed in 2006, there were 831 territories detected.

- Most territories are found within small breeding sites (those sites with five or fewer territories). There are only six sites with 50 or more territories, though this comparison is confounded by lack of a standard definition of site.

- We know of 135 sites that at one time had flycatcher since 1993, but as of 2006 do not contain flycatcher territories - almost all were small sites (five or fewer territories). Because these were primarily small sites, these territory losses account for only a small percentage of known territories; however, they underscore the vulnerability of small sites.

- The states of California, Arizona, and New Mexico account for $88 \%$ of known flycatcher territories. Nevada, Colorado, and Utah collectively have $12 \%$ of the known territories. We have received no reporting from standardized Southwestern Willow Flycatcher surveys in Texas, and hence know nothing of the current status of the flycatcher there.

- Southwestern Willow Flycatchers are distributed over a wide elevation range, with most from sea level to $1600 \mathrm{~m}$, but a few sites (n=3) are located as high as $2500 \mathrm{~m}$ in elevation.

- Fewer than half (43\%) of territories are in native habitat and $28 \%$ are in habitats having a $50 \%$ or greater exotic component. A large percentage of the territories in native habitat occur at one site - the Cliff-Gila Valley in New Mexico. Over $90 \%$ of territories are in habitats where willow, saltcedar, or boxelder are the dominant tree species; flycatchers breed in boxelder-dominated habitats only in the Cliff-Gila Valley, New Mexico.

- Fewer than half (44\%) of sites are on federally-controlled lands and $28 \%$ are on private lands; these privately owned sites account for $36 \%$ of known territories. Approximately one-third (32\%) of territories on privately owned sites are found in the Cliff-Gila Valley, New Mexico. 


\section{Acknowledgements}

This synthesis of data from so many sites over such a broad geographic range was only made possible by the efforts of numerous cooperators. Originally, these data were gathered by hundreds of agency and non-governmental biologists surveying for thousands of hours, often in very difficult field conditions. Their dedication and efforts are greatly appreciated. Further, the ability to report specific information for each site was aided by agencies and people that provided detailed summary information; our sincere thanks go to the individuals listed below.

For Arizona: Lisa Ellis, Heather English, Alex Smith, Oliva Munzer and April Tudor (all of the Arizona Game and Fish Department); Greg Beatty (USFWS); and Kerry Christensen (Hualapai Tribe). For California: Kerry Kenwood and Jay Rourke (USGS); Peter Bloom, Mary Anne McLeod, and Tom Koronkiewicz (SWCA, Inc.); Pete Famolaro (Sweetwater Authority); Jim Greaves; William Haas (Varanus Biological Services); Loren Hays (USFWS); Mark Holmgren; David Pereksta (USFWS); and Mary Whitfield (Kern River Research Center). For Colorado: Mike Fitzgerald, and Lynn Alterman (Ecosphere); Kelli Stone and Terry Ireland (USFWS); Jill Lucero (BLM); and Mike Stake (Hawks Aloft). For Nevada: Jeri Krueger (USFWS); Robert McKernan (SBCM); Cris Tomlinson and Christina Klinger (Nevada Division of Wildlife); Mary Anne McLeod and Tom Koronkiewicz (SWCA, Inc.) For New Mexico: Rob Doster, Darrel Ahlers, and Francoise Leonard (US Bureau of Reclamation); and Nancy Baczek (USFWS). For Utah: Keith Day (BLM) and Frank Howe (Utah Division of Wildlife Resources).

This project was sponsored in part using federal funds from the U.S. Geological Survey and the U.S. Bureau of Reclamation (Phoenix Area Office).

\section{Literature Cited}

Browning, M.R. 1993. Comments on the taxonomy of Empidonax traillii (Willow Flycatcher). Western Birds 19:25-33.

Cardinal, S.N. and E.H. Paxton. 2005. Home range, movement, and habitat use of the Southwestern Willow Flycatcher, Roosevelt Lake, AZ - 2004. U.S. Geological Survey report to the U.S. Bureau of Reclamation, Phoenix.

Cardinal, S.N., E.H. Paxton, and S.L. Durst. 2006. Home range, movement, and habitat use of the Southwestern Willow Flycatcher, Roosevelt Lake, AZ - 2005. U.S. Geological Survey report to the U.S. Bureau of Reclamation, Phoenix.

Causey, C.F., S.L. Durst, P.J. Newell, M.G. Pollock, E.H. Paxton, and M.K. Sogge. 2005. Survivorship and movements of Southwestern Willow Flycatchers at Roosevelt Lake, Arizona - 2005. U.S. Geological Survey report to the U.S Bureau of Reclamation, Phoneix. 
Hatten, J.R., and C.E. Paradzick. 2003. A multiscaled model of southwestern willow flycatcher breeding habitat. Journal of Wildlife Management 67: 774-788.

Netter, M.R., E.H. Paxton and M.K. Sogge. 1998. Banding and movements of the Southwestern Willow Flycatcher at Roosevelt Lake and San Pedro River/Gila River confluence, Arizona - 1998. USGS Colorado Plateau Field Station Report.

Paxton, E.H. 2000. Molecular genetic structuring and demographic history of the Willow Flycatcher. Masters Thesis. Northern Arizona University, Flagstaff, AZ.

Paxton, E. and M.K. Sogge. 1996. Banding and population genetics of Southwestern Willow Flycatchers in Arizona - 1996 Summary Report. USGS Colorado Plateau Field Station Report.

Paxton, E.H, S. Langridge, and M.K. Sogge. 1997. Banding and population genetics of Southwestern Willow Flycatchers in Arizona - 1997 Summary Report. USGS Colorado Plateau Field Station Report.

Paxton, E.H., M.K. Sogge, T.C. Theimer, and J. Hatten. 2007. The Ecology of the Southwestern Willow Flycatcher in Central Arizona: A 10-year Synthesis Report. USGS Open File Report 2007-1381 http://pubs.usgs.gov/of/2007/1381.

Sedgwick, J.A. 2001. Geographic variation in the song of Willow Flycatchers: differentiation between Empidonax traillii adastus and E.t. extimus. Auk 118:366379.

Sogge, M.K., R.M. Marshall, S.J. Sferra and T.J. Tibbitts. 1997. A Southwestern Willow Flycatcher natural history summary and survey protocol. National Park Service Technical Report NPS/NAUCPRS/NRTR-97/12.

Sogge, M. K., S. J. Sferra, T. D. McCarthey, S. O. Williams, and B. E. Kus. 2000. Southwestern Willow Flycatcher breeding site and territory summary - 1999. U.S. Geological Survey, Flagstaff, AZ.

Stoleson, S.H. and D.M. Finch. 2003. Microhabitat use by breeding Southwestern Willow Flycatchers on the Gila River, New Mexico. Studies in Avian Biology 26:91-95.

Unitt, P. 1987. Empidonax traillii extimus: an endangered subspecies. Western Birds 18:137-162.

U.S. Fish and Wildlife Service. 2002. Final Southwestern Willow Flycatcher Recovery Plan. U.S. Fish and Wildlife Service, Albuquerque, NM. 
Appendix 1. Distribution of sites and territories by year and state based on both estimated and surveyed values. Data for years prior to 2006 reflect the actual surveys conducted in the year and estimates based on the most recent surveys prior to that year. These updated numbers may differ from past reports.

\begin{tabular}{|c|c|c|c|c|c|c|c|c|c|}
\hline \multirow[b]{2}{*}{ Year } & \multicolumn{5}{|c|}{ Estimated Sites and Territories } & \multicolumn{4}{|c|}{ Surveyed Sites and Territories } \\
\hline & State & \# Sites & $\begin{array}{c}\text { \% of } \\
\text { Total } \\
\text { Sites } \\
\text { by } \\
\text { Year }\end{array}$ & \# Terr. & $\begin{array}{c}\text { \% of } \\
\text { Total } \\
\text { Terr. } \\
\text { by } \\
\text { Year }\end{array}$ & \# Sites & $\begin{array}{c}\text { \% of } \\
\text { Total } \\
\text { Sites } \\
\text { by } \\
\text { Year }\end{array}$ & \# Terr. & $\begin{array}{c}\% \text { of } \\
\text { Total } \\
\text { Terr. } \\
\text { by } \\
\text { Year }\end{array}$ \\
\hline \multirow{7}{*}{2006} & $A Z$ & 123 & 43.3 & 482 & 38.2 & 78 & 61.9 & 349 & 42.0 \\
\hline & $\mathrm{CA}$ & 96 & 33.8 & 190 & 15.1 & 14 & 11.1 & 44 & 5.3 \\
\hline & $\mathrm{CO}$ & 11 & 3.9 & 58 & 4.6 & 1 & 0.8 & 0 & 0.0 \\
\hline & NM & 38 & 13.4 & 443 & 35.1 & 21 & 16.7 & 361 & 43.4 \\
\hline & $\mathrm{NV}$ & 13 & 4.6 & 82 & 6.5 & 10 & 7.9 & 70 & 8.4 \\
\hline & UT & 3 & 1.1 & 7 & 0.6 & 2 & 1.6 & 7 & 0.8 \\
\hline & TOTAL & 284 & & 1262 & & 126 & & 831 & \\
\hline \multirow{7}{*}{2005} & $A Z$ & 113 & 42.3 & 492 & 40.9 & 88 & 59.1 & 481 & 48.1 \\
\hline & CA & 93 & 34.8 & 192 & 16.0 & 21 & 14.1 & 47 & 4.7 \\
\hline & $\mathrm{CO}$ & 10 & 3.7 & 58 & 4.8 & 3 & 2.0 & 48 & 4.8 \\
\hline & NM & 37 & 13.9 & 389 & 32.4 & 25 & 16.8 & 365 & 36.5 \\
\hline & NV & 11 & 4.1 & 67 & 5.6 & 9 & 6.0 & 55 & 5.5 \\
\hline & UT & 3 & 1.1 & 4 & 0.3 & 3 & 2.0 & 4 & 0.4 \\
\hline & TOTAL & 267 & & 1202 & & 149 & & 1000 & \\
\hline \multirow{7}{*}{2004} & $A Z$ & 105 & 42.0 & 516 & 44.3 & 86 & 53.8 & 508 & 49.1 \\
\hline & $\mathrm{CA}$ & 90 & 36.0 & 197 & 16.9 & 33 & 20.6 & 109 & 10.5 \\
\hline & $\mathrm{CO}$ & 10 & 4.0 & 51 & 4.4 & 7 & 4.4 & 47 & 4.5 \\
\hline & NM & 31 & 12.4 & 325 & 27.9 & 22 & 13.8 & 308 & 29.8 \\
\hline & NV & 11 & 4.4 & 68 & 5.8 & 9 & 5.6 & 56 & 5.4 \\
\hline & UT & 3 & 1.2 & 7 & 0.6 & 3 & 1.9 & 7 & 0.7 \\
\hline & TOTAL & 250 & & 1164 & & 160 & & 1035 & \\
\hline \multirow{7}{*}{2003} & $A Z$ & 104 & 42.6 & 420 & 39.1 & 91 & 53.8 & 412 & 43.4 \\
\hline & CA & 86 & 35.2 & 196 & 18.3 & 38 & 22.5 & 113 & 11.9 \\
\hline & $\mathrm{CO}$ & 9 & 3.7 & 79 & 7.4 & 6 & 3.6 & 75 & 7.9 \\
\hline & NM & 31 & 12.7 & 306 & 28.5 & 22 & 13.0 & 289 & 30.5 \\
\hline & NV & 11 & 4.5 & 64 & 6.0 & 9 & 5.3 & 52 & 5.5 \\
\hline & UT & 3 & 1.2 & 8 & 0.7 & 3 & 1.8 & 8 & 0.8 \\
\hline & TOTAL & 244 & & 1073 & & 169 & & 949 & \\
\hline
\end{tabular}


2006 Southwestern Willow Flycatcher Rangewide Summary

\begin{tabular}{|c|c|c|c|c|c|c|c|c|c|}
\hline \multirow[b]{2}{*}{ Year } & \multicolumn{5}{|c|}{ Estimated Sites and Territories } & \multicolumn{4}{|c|}{ Surveyed Sites and Territories } \\
\hline & State & \# Sites & $\begin{array}{l}\text { \% of } \\
\text { Total } \\
\text { Sites } \\
\text { by } \\
\text { Year }\end{array}$ & \# Terr. & $\begin{array}{c}\% \text { of } \\
\text { Total } \\
\text { Terr. } \\
\text { by } \\
\text { Year }\end{array}$ & \# Sites & $\begin{array}{c}\% \text { of } \\
\text { Total } \\
\text { Sites } \\
\text { by } \\
\text { Year }\end{array}$ & \# Terr. & $\begin{array}{c}\% \text { of } \\
\text { Total } \\
\text { Terr. } \\
\text { by } \\
\text { Year }\end{array}$ \\
\hline \multirow{7}{*}{2002} & $A Z$ & 95 & 42.2 & 456 & 42.3 & 86 & 50.0 & 450 & 45.9 \\
\hline & $\mathrm{CA}$ & 74 & 32.9 & 195 & 18.1 & 38 & 22.1 & 130 & 13.3 \\
\hline & $\mathrm{CO}$ & 10 & 4.4 & 60 & 5.6 & 9 & 5.2 & 59 & 6.0 \\
\hline & NM & 32 & 14.2 & 312 & 29.0 & 27 & 15.7 & 299 & 30.5 \\
\hline & NV & 11 & 4.9 & 49 & 4.5 & 9 & 5.2 & 37 & 3.8 \\
\hline & UT & 3 & 1.3 & 5 & 0.5 & 3 & 1.7 & 5 & 0.5 \\
\hline & TOTAL & 225 & & 1077 & & 172 & & 980 & \\
\hline \multirow{7}{*}{2001} & $A Z$ & 92 & 42.6 & 351 & 40.7 & 84 & 43.5 & 345 & 41.6 \\
\hline & CA & 83 & 38.4 & 220 & 25.5 & 73 & 37.8 & 206 & 24.8 \\
\hline & $\mathrm{CO}$ & 1 & 0.5 & 1 & 0.1 & 0 & 0.0 & 0 & 0.0 \\
\hline & NM & 25 & 11.6 & 215 & 24.9 & 21 & 10.9 & 202 & 24.4 \\
\hline & $\mathrm{NV}$ & 12 & 5.6 & 73 & 8.5 & 12 & 6.2 & 73 & 8.8 \\
\hline & UT & 3 & 1.4 & 3 & 0.3 & 3 & 1.6 & 3 & 0.4 \\
\hline & TOTAL & 216 & & 863 & & 193 & & 829 & \\
\hline \multirow{7}{*}{2000} & $A Z$ & 87 & 42.0 & 337 & 39.8 & 80 & 42.6 & 331 & 40.3 \\
\hline & $\mathrm{CA}$ & 74 & 35.7 & 185 & 21.9 & 65 & 34.6 & 171 & 20.8 \\
\hline & $\mathrm{CO}$ & 1 & 0.5 & 1 & 0.1 & 1 & 0.5 & 1 & 0.1 \\
\hline & NM & 31 & 15.0 & 257 & 30.4 & 28 & 14.9 & 252 & 30.7 \\
\hline & NV & 11 & 5.3 & 56 & 6.6 & 11 & 5.9 & 56 & 6.8 \\
\hline & UT & 3 & 1.4 & 10 & 1.2 & 3 & 1.6 & 10 & 1.2 \\
\hline & TOTAL & 207 & & 846 & & 188 & & 821 & \\
\hline \multirow{7}{*}{1999} & $A Z$ & 92 & 49.5 & 295 & 36.4 & 87 & 50.3 & 290 & 36.7 \\
\hline & $\mathrm{CA}$ & 66 & 35.5 & 193 & 23.8 & 60 & 34.7 & 184 & 23.3 \\
\hline & $\mathrm{CO}$ & 0 & 0.0 & 0 & 0.0 & 0 & 0.0 & 0 & 0.0 \\
\hline & NM & 22 & 11.8 & 300 & 37.0 & 20 & 11.6 & 295 & 37.3 \\
\hline & NV & 5 & 2.7 & 17 & 2.1 & 5 & 2.9 & 17 & 2.1 \\
\hline & UT & 1 & 0.5 & 5 & 0.6 & 1 & 0.6 & 5 & 0.6 \\
\hline & TOTAL & 186 & & 810 & & 173 & & 791 & \\
\hline \multirow{7}{*}{1998} & $A Z$ & 97 & 57.1 & 223 & 33.1 & 94 & 58.4 & 221 & 33.4 \\
\hline & $\mathrm{CA}$ & 41 & 24.1 & 137 & 20.3 & 37 & 23.0 & 131 & 19.8 \\
\hline & $\mathrm{CO}$ & 1 & 0.6 & 1 & 0.1 & 1 & 0.6 & 1 & 0.2 \\
\hline & NM & 21 & 12.4 & 262 & 38.9 & 19 & 11.8 & 257 & 38.9 \\
\hline & NV & 8 & 4.7 & 30 & 4.5 & 8 & 5.0 & 30 & 4.5 \\
\hline & UT & 2 & 1.2 & 21 & 3.1 & 2 & 1.2 & 21 & 3.2 \\
\hline & TOTAL & 170 & & 674 & & 161 & & 661 & \\
\hline
\end{tabular}


2006 Southwestern Willow Flycatcher Rangewide Summary

\begin{tabular}{|c|c|c|c|c|c|c|c|c|c|}
\hline \multirow[b]{2}{*}{ Year } & \multicolumn{5}{|c|}{ Estimated Sites and Territories } & \multicolumn{4}{|c|}{ Surveyed Sites and Territories } \\
\hline & State & \# Sites & $\begin{array}{l}\text { \% of } \\
\text { Total } \\
\text { Sites } \\
\text { by } \\
\text { Year }\end{array}$ & \# Terr. & $\begin{array}{c}\% \text { of } \\
\text { Total } \\
\text { Terr. } \\
\text { by } \\
\text { Year }\end{array}$ & \# Sites & $\begin{array}{c}\% \text { of } \\
\text { Total } \\
\text { Sites } \\
\text { by } \\
\text { Year }\end{array}$ & \# Terr. & $\begin{array}{c}\% \text { of } \\
\text { Total } \\
\text { Terr. } \\
\text { by } \\
\text { Year }\end{array}$ \\
\hline \multirow{7}{*}{1997} & $A Z$ & 67 & 50.0 & 188 & 30.7 & 66 & 51.2 & 188 & 31.1 \\
\hline & $\mathrm{CA}$ & 38 & 28.4 & 118 & 19.2 & 36 & 27.9 & 115 & 19.0 \\
\hline & $\mathrm{CO}$ & 3 & 2.2 & 35 & 5.7 & 3 & 2.3 & 35 & 5.8 \\
\hline & NM & 20 & 14.9 & 243 & 39.6 & 18 & 14.0 & 238 & 39.3 \\
\hline & NV & 5 & 3.7 & 18 & 2.9 & 5 & 3.9 & 18 & 3.0 \\
\hline & UT & 1 & 0.7 & 11 & 1.8 & 1 & 0.8 & 11 & 1.8 \\
\hline & TOTAL & 134 & & 613 & & 129 & & 605 & \\
\hline \multirow{7}{*}{1996} & $A Z$ & 45 & 45.0 & 145 & 30.5 & 44 & 45.4 & 145 & 30.7 \\
\hline & $\mathrm{CA}$ & 27 & 27.0 & 118 & 24.8 & 26 & 26.8 & 117 & 24.7 \\
\hline & $\mathrm{CO}$ & 0 & 0.0 & 0 & 0.0 & 0 & 0.0 & 0 & 0.0 \\
\hline & NM & 25 & 25.0 & 208 & 43.7 & 24 & 24.7 & 206 & 43.6 \\
\hline & $\mathrm{NV}$ & 2 & 2.0 & 3 & 0.6 & 2 & 2.1 & 3 & 0.6 \\
\hline & UT & 1 & 1.0 & 2 & 0.4 & 1 & 1.0 & 2 & 0.4 \\
\hline & TOTAL & 100 & & 476 & & 97 & & 473 & \\
\hline \multirow{7}{*}{1995} & $A Z$ & 25 & 39.7 & 84 & 24.1 & 24 & 39.3 & 84 & 24.3 \\
\hline & $\mathrm{CA}$ & 18 & 28.6 & 89 & 25.6 & 18 & 29.5 & 89 & 25.7 \\
\hline & $\mathrm{CO}$ & 0 & 0.0 & 0 & 0.0 & 0 & 0.0 & 0 & 0.0 \\
\hline & NM & 18 & 28.6 & 172 & 49.4 & 17 & 27.9 & 170 & 49.1 \\
\hline & NV & 1 & 1.6 & 1 & 0.3 & 1 & 1.6 & 1 & 0.3 \\
\hline & UT & 1 & 1.6 & 2 & 0.6 & 1 & 1.6 & 2 & 0.6 \\
\hline & TOTAL & 63 & & 348 & & 61 & & 346 & \\
\hline \multirow{7}{*}{1994} & $A Z$ & 25 & 47.2 & 111 & 30.7 & 25 & 48.1 & 111 & 30.9 \\
\hline & $\mathrm{CA}$ & 10 & 18.9 & 84 & 23.3 & 10 & 19.2 & 84 & 23.4 \\
\hline & $\mathrm{CO}$ & 0 & 0.0 & 0 & 0.0 & 0 & 0.0 & 0 & 0.0 \\
\hline & NM & 18 & 34.0 & 166 & 46.0 & 17 & 32.7 & 164 & 45.7 \\
\hline & NV & 0 & 0.0 & 0 & 0.0 & 0 & 0.0 & 0 & 0.0 \\
\hline & UT & 0 & 0.0 & 0 & 0.0 & 0 & 0.0 & 0 & 0.0 \\
\hline & TOTAL & 53 & & 361 & & 52 & & 359 & \\
\hline \multirow{7}{*}{1993} & $A Z$ & 17 & 42.5 & 33 & 23.6 & 17 & 42.5 & 33 & 23.6 \\
\hline & $\mathrm{CA}$ & 7 & 17.5 & 75 & 53.6 & 7 & 17.5 & 75 & 53.6 \\
\hline & $\mathrm{CO}$ & 0 & 0.0 & 0 & 0.0 & 0 & 0.0 & 0 & 0.0 \\
\hline & NM & 16 & 40.0 & 32 & 22.9 & 16 & 40.0 & 32 & 22.9 \\
\hline & NV & 0 & 0.0 & 0 & 0.0 & 0 & 0.0 & 0 & 0.0 \\
\hline & UT & 0 & 0.0 & 0 & 0.0 & 0 & 0.0 & 0 & 0.0 \\
\hline & TOTAL & 40 & & 140 & & 40 & & 140 & \\
\hline
\end{tabular}


Appendix 2. List of the 135 sites that at one time had Southwestern Willow Flycatcher territories, but were unoccupied as of the most recent survey (zero territories for one or more years). The most recent survey year is indicated.

We term these "extirpated" sites, though it is important to recognize that a particular site could become occupied again in the future. If flycatchers are detected at any site in subsequent years, that site will no longer be considered "extirpated" and would be removed sites from this list. In past years there have been 45 sites that were unoccupied for one or more years but were subsequently reoccupied by flycatchers.

\begin{tabular}{|c|c|c|c|c|}
\hline Site Name & Site Code & Year & State & Reference \\
\hline $\begin{array}{l}\text { Agua Hedionda - } \\
\text { Macario Canyon }\end{array}$ & AHMACA & 2001 & CA & W. Haas per Kus 2002 table \\
\hline $\begin{array}{l}\text { Ash Meadows NWR - } \\
\text { Carson Slough }\end{array}$ & AMAMCS & 2006 & NV & Klinger and Furtek 2007 \\
\hline $\begin{array}{l}\text { Amargosa River - Oasis } \\
\text { Valley - Springdale }\end{array}$ & AMOVSP & 2006 & NV & Klinger and Furtek 2007 \\
\hline Bill Williams Buckskin & BWBUCK & 2006 & $A Z$ & Graber et al. 2007 \\
\hline $\begin{array}{l}\text { Bill Williams - Cave } \\
\text { Wash }\end{array}$ & BWCAVE & 2006 & $A Z$ & Graber et al. 2007 \\
\hline $\begin{array}{l}\text { Bill Williams Delta } \\
\text { Marsh Edge }\end{array}$ & BWDEMA & 2006 & $A Z$ & Graber et al. 2007 \\
\hline Bill Williams Gemini & BWGEMI & 2006 & $A Z$ & Graber et al. 2007 \\
\hline Parkview Fish Hatch & CHPARK & 2001 & NM & Williams 2002 \\
\hline $\begin{array}{l}\text { Colorado River - Grand } \\
\text { Cyn RM } 246 \text { L }\end{array}$ & CO246L & 2006 & $A Z$ & Graber et al. 2007 \\
\hline $\begin{array}{l}\text { Colorado River - Miles } \\
257.5 \text { to } 257.0 \mathrm{R}\end{array}$ & CO257R & 2005 & $A Z$ & English et al. 2006 \\
\hline $\begin{array}{l}\text { Colorado River - Grand } \\
\text { Cyn RM } 259.5 \text { L }\end{array}$ & CO259L & 2005 & $A Z$ & English et al. 2006 \\
\hline $\begin{array}{l}\text { Colorado River - Grand } \\
\text { Cyn RM } 259 \text { R }\end{array}$ & CO259R & 2006 & $A Z$ & Graber et al. 2007 \\
\hline $\begin{array}{l}\text { Colorado River - Grand } \\
\text { Cyn RM 263-262 L }\end{array}$ & CO263L & 2004 & $A Z$ & Munzer et al. 2005 \\
\hline $\begin{array}{l}\text { Colorado River - Grand } \\
\text { Cyn RM 265-263 L }\end{array}$ & CO265L & 2003 & $A Z$ & Smith et al. 2004 \\
\hline $\begin{array}{l}\text { Colorado River - Grand } \\
\text { Cyn RM 268-265 L }\end{array}$ & CO268L & 2003 & $A Z$ & Smith et al. 2004 \\
\hline $\begin{array}{l}\text { Colorado River - Grand } \\
\text { Cyn RM 268-264 R }\end{array}$ & CO268R & 2004 & $A Z$ & Munzer et al. 2005 \\
\hline $\begin{array}{l}\text { Colorado River - Grand } \\
\text { Cyn RM 270-268 L }\end{array}$ & CO270L & 2003 & $A Z$ & Smith et al. 2004 \\
\hline $\begin{array}{l}\text { Colorado River - Grand } \\
\text { Cyn RM 272-268 R }\end{array}$ & $\mathrm{CO} 272 \mathrm{R}$ & 2004 & $A Z$ & Munzer et al. 2005 \\
\hline $\begin{array}{l}\text { Colorado River - Grand } \\
\text { Cyn RM 273-270 L }\end{array}$ & CO273L & 2002 & $A Z$ & Smith et al. 2003 \\
\hline $\begin{array}{l}\text { Colorado River - Grand } \\
\text { Cyn RM 277-273 L }\end{array}$ & CO277L & 2006 & $A Z$ & Graber et al. 2007 \\
\hline
\end{tabular}


2006 Southwestern Willow Flycatcher Rangewide Summary

\begin{tabular}{|c|c|c|c|c|}
\hline Site Name & Site Code & Year & State & Reference \\
\hline $\begin{array}{l}\text { Colorado River - Adobe } \\
\text { Lake }\end{array}$ & COADOB & 2006 & $A Z$ & Graber et al. 2007 \\
\hline $\begin{array}{l}\text { Colorado River - Big } \\
\text { Hole Slough }\end{array}$ & COBHSL & 2005 & CA & Koronkiewicz et al. 2006 \\
\hline $\begin{array}{l}\text { Colorado River } \\
\text { Blankenship }\end{array}$ & COBLAN & 2006 & $A Z$ & Graber et al. 2007 \\
\hline $\begin{array}{l}\text { Colorado River - Cibola } \\
\text { SW Landing Strip }\end{array}$ & COCIBO & 2006 & $A Z$ & Graber et al. 2007 \\
\hline $\begin{array}{l}\text { Colorado River - Draper } \\
\text { Lake }\end{array}$ & CODRAP & 2001 & CA & Smith et al. 2002 \\
\hline $\begin{array}{l}\text { Colorado River - } \\
\text { Ferguson Lake }\end{array}$ & COFERG & 2005 & $A Z$ & Koronkiewicz et al. 2006 \\
\hline $\begin{array}{l}\text { Colorado River - Grand } \\
\text { Canyon RM 28-29 }\end{array}$ & COGC29 & 2005 & $A Z$ & English et al. 2006 \\
\hline $\begin{array}{l}\text { Colorado River - Grand } \\
\text { Canyon RM 50-51 L }\end{array}$ & COGC50 & 2005 & $A Z$ & English et al. 2006 \\
\hline $\begin{array}{l}\text { Colorado River - Grand } \\
\text { Canyon RM } 65.3 \text { L }\end{array}$ & COGC65 & 2004 & $A Z$ & Munzer et al. 2005 \\
\hline $\begin{array}{l}\text { Colorado River - Grand } \\
\text { Canyon RM } 71 \text { L }\end{array}$ & COGC71 & 2005 & $A Z$ & English et al. 2006 \\
\hline $\begin{array}{l}\text { Colorado River - Gila } \\
\text { Confluence } 1\end{array}$ & COGILA & 2006 & $A Z$ & Graber et al. 2007 \\
\hline Lake Havasu - Neptune & COHAVA & 2006 & $A Z$ & Graber et al. 2007 \\
\hline Colorado River - Hoge & COHOGE & 2006 & $A Z$ & Graber et al. 2007 \\
\hline $\begin{array}{l}\text { Kanab Creek - Town of } \\
\text { Kanab }\end{array}$ & COKANB & 2005 & UT & Day 2005 \\
\hline $\begin{array}{l}\text { Colorado River - Mittry } \\
\text { Lake }\end{array}$ & COMITT & 2006 & $A Z$ & Graber et al. 2007 \\
\hline $\begin{array}{l}\text { Colorado River - } \\
\text { Picacho East }\end{array}$ & COPICA & 2005 & CA & Koronkiewicz et al. 2006 \\
\hline $\begin{array}{l}\text { Colorado River - Taylor } \\
\text { Lake }\end{array}$ & COTAYL & 2005 & CA & Kenwood May 2007 file \\
\hline $\begin{array}{l}\text { Colorado River - } \\
\text { Trampas Wash }\end{array}$ & COTRAM & 2005 & CA & Kenwood file May 2007 \\
\hline $\begin{array}{l}\text { Colorado River - } \\
\text { Waterwheel Cove }\end{array}$ & COWACO & 2006 & $A Z$ & Graber et al. 2007 \\
\hline $\begin{array}{l}\text { Colorado River - Walker } \\
\text { Lake }\end{array}$ & COWALK & 2005 & CA & Kennwood file May 2007 \\
\hline Gila River - Dysart Road & GIDYSA & 2003 & $A Z$ & Smith et al. 2004 \\
\hline Gila River - Earven Flat & GIEAFL & 2005 & $A Z$ & English et al. 2005 \\
\hline $\begin{array}{l}\text { Gila River - Fortuna } \\
\text { Wash }\end{array}$ & GIFOWA & 2006 & $A Z$ & Graber et al. 2007 \\
\hline $\begin{array}{l}\text { Gila River - Fort } \\
\text { Thomas Bridge }\end{array}$ & GIFTBR & 1994 & $A Z$ & Paradzick et al. 2001 \\
\hline Gila River - GRSN031 & GIGI31 & 2006 & $A Z$ & Graber et al. 2007 \\
\hline Gila River GRN010 & GIGN10 & 2006 & $A Z$ & Graber et al. 2007 \\
\hline Gila River GRN011 & GIGN11 & 2000 & $A Z$ & Paradzick et al. 2001 \\
\hline
\end{tabular}


2006 Southwestern Willow Flycatcher Rangewide Summary

\begin{tabular}{|c|c|c|c|c|}
\hline Site Name & Site Code & Year & State & Reference \\
\hline Gila River GRN015 & GIGN15 & 2002 & $A Z$ & Smith et al. 2003 \\
\hline Gila River - GRN 033 & GIGN33 & 2006 & $A Z$ & Graber et al. 2007 \\
\hline Gila River - GRS011 & GIGS11 & 2006 & $A Z$ & Graber et al. 2007 \\
\hline Gila River GRS012 & GIGS12 & 2006 & $A Z$ & Graber et al. 2007 \\
\hline Gila River GRS013 & GIGS13 & 2003 & $A Z$ & Smith et al. 2004 \\
\hline Gila River GRS015 & GIGS15 & 2002 & $A Z$ & Smith et al. 2003 \\
\hline Gila River - Guthrie & GIGUTH & 2006 & $A Z$ & Graber et al. 2007 \\
\hline Gila River - San Jose & GISAJO & 2001 & $A Z$ & Smith et al. 2002 \\
\hline $\begin{array}{l}\text { Gila River - Smithville } \\
\text { Canal }\end{array}$ & GISMIT & 1997 & $A Z$ & McCarthey et al. 1998 \\
\hline $\begin{array}{l}\text { Gila River - Solomon } \\
\text { NW }\end{array}$ & GISONW & 2006 & $A Z$ & Graber et al. 2007 \\
\hline $\begin{array}{l}\text { Gila River - Whitlow } \\
\text { Dam }\end{array}$ & GIWHDA & 2006 & $A Z$ & Graber et al. 2007 \\
\hline Canebreak Preserve & KECANE & 2003 & $\mathrm{CA}$ & $\begin{array}{l}\text { Jones and Stokes from Kus } \\
2003\end{array}$ \\
\hline Nelson Reservoir & LCNERE & 2006 & $A Z$ & Graber et al 2007 \\
\hline Las Flores Creek & LFLAFL & 2006 & $\mathrm{CA}$ & Kenwood file May 2007 \\
\hline $\begin{array}{l}\text { Holcomb Creek - Little } \\
\text { Bear Springs }\end{array}$ & MOLBRS & 2004 & $\mathrm{CA}$ & K. Kenwood file Sept 2005 \\
\hline $\begin{array}{l}\text { Mojave River - Oro } \\
\text { Grande }\end{array}$ & MOORGR & 2004 & CA & K. Kenwood file Sept 2005 \\
\hline $\begin{array}{l}\text { Mojave River, Upper } \\
\text { Narrows }\end{array}$ & MOUPNA & 2006 & $\mathrm{CA}$ & Kenwood file May 2007 \\
\hline $\begin{array}{l}\text { Mojave River, Victorville } \\
\text { I-15 }\end{array}$ & MOVICT & 2004 & $\mathrm{CA}$ & K. Kenwood file Sept 2005 \\
\hline $\begin{array}{l}\text { Meadow Valley Wash - } \\
\text { Site } 1\end{array}$ & MVMV01 & 2006 & NV & Klinger and Furtek 2007 \\
\hline $\begin{array}{l}\text { Pahranagat River - } \\
\text { Crystal Springs }\end{array}$ & PACRSP & 2005 & NV & Furtek and Tomlinson 2006 \\
\hline Sulphur Creek & PHSUCR & 2003 & $\mathrm{CA}$ & $\begin{array}{l}\text { J. Berkeley - Kus/Kenwood } \\
\text { table }\end{array}$ \\
\hline Bluewater Creek & RIBLUE & 2006 & NM & Baczek email 3/07 \\
\hline $\begin{array}{l}\text { Rio Grande Velarde-El } \\
\text { Guique }\end{array}$ & RIELGU & 2002 & NM & Williams email 3/03 \\
\hline $\begin{array}{l}\text { Rio Grande Velarde- } \\
\text { Garcia Acequia }\end{array}$ & RIGARC & 2006 & NM & Baczek email 3/07 \\
\hline $\begin{array}{l}\text { Rio Grande - Hot Creek } \\
\text { SWA }\end{array}$ & RIHTSW & 2004 & $\mathrm{CO}$ & Ecosphere 2006 \\
\hline $\begin{array}{l}\text { Rio Grande Velarde-La } \\
\text { Canova }\end{array}$ & RILACA & 2006 & NM & Baczek email 3/07 \\
\hline $\begin{array}{l}\text { Rio Grande Velarde-La } \\
\text { Rinconada }\end{array}$ & RILARI & 2006 & NM & Baczek email 3/07 \\
\hline Rio Grande Orilla Verde & RIORIL & 2006 & NM & Baczek email 3/07 \\
\hline $\begin{array}{l}\text { Rio Grande - Casa } \\
\text { Colorado }\end{array}$ & RIRGCC & 2006 & NM & Baczek email 3/07 \\
\hline
\end{tabular}


2006 Southwestern Willow Flycatcher Rangewide Summary

\begin{tabular}{|c|c|c|c|c|}
\hline Site Name & Site Code & Year & State & Reference \\
\hline $\begin{array}{l}\text { Rio Grande Taos } \\
\text { Junction Bridg }\end{array}$ & RITAOS & 2006 & NM & Baczek email 3/07 \\
\hline $\begin{array}{l}\text { Santa Ana River - SR } \\
38 \text { Bridge Crossing }\end{array}$ & SA38BC & 2005 & CA & Kenwood file May 2007 \\
\hline $\begin{array}{l}\text { Santa Ana River - Bear } \\
\text { Creek }\end{array}$ & SABEAR & 2004 & CA & K. Kenwood file Sept 2005 \\
\hline $\begin{array}{l}\text { Santa Ana River - City } \\
\text { Creek }\end{array}$ & SACICR & 2002 & CA & K. Kenwood file Sept 2005 \\
\hline $\begin{array}{l}\text { Santa Ana River - Deer } \\
\text { Creek }\end{array}$ & SADEER & 2004 & CA & K. Kenwood file Sept 2005 \\
\hline $\begin{array}{l}\text { Santa Ana River - East } \\
\text { Etiwanda Creek }\end{array}$ & SAEECR & 2001 & CA & K. Kenwood file May 2006 \\
\hline $\begin{array}{l}\text { Santa Ana River - } \\
\text { Featherly Regional Park }\end{array}$ & SAFEAT & 2001 & CA & Kenwood Table 04/2005 \\
\hline $\begin{array}{l}\text { Santa Ana River - La } \\
\text { Cadena to Waterman }\end{array}$ & SALACA & 2004 & CA & K. Kenwood file Sept 2005 \\
\hline $\begin{array}{l}\text { Santa Ana River - } \\
\text { Metcalf Creek }\end{array}$ & SAMECR & 2004 & CA & K. Kenwood file May 2006 \\
\hline $\begin{array}{l}\text { Santa Ana River - Mtn } \\
\text { Home Village }\end{array}$ & SAMTNH & 2004 & CA & K. Kenwood file May 2006 \\
\hline $\begin{array}{l}\text { Santa Ana River - } \\
\text { Rattlesnake Creek }\end{array}$ & SARTSN & 2004 & CA & K. Kenwood file Sept 2005 \\
\hline $\begin{array}{l}\text { Santa Ana River - San } \\
\text { Timoteo Creek }\end{array}$ & SASNTI & 2006 & CA & Kenwood file May 2007 \\
\hline $\begin{array}{l}\text { Santa Ana River - } \\
\text { Strawberry Creek }\end{array}$ & SASTCR & 2000 & CA & $\begin{array}{l}\text { D. Guthrie pers comm from } \\
\text { B.Kus }\end{array}$ \\
\hline $\begin{array}{l}\text { Santa Ana River - Van } \\
\text { Dusen Canyon }\end{array}$ & SAVDCA & 2002 & CA & $\begin{array}{l}\text { K. Kenwood data file Sept } \\
2005\end{array}$ \\
\hline $\begin{array}{l}\text { Santa Ana River - } \\
\text { Waterman Creek }\end{array}$ & SAWACR & 2001 & CA & SBCM per Kus 2002 table \\
\hline San Gabrial River & SBSAGA & 2005 & CA & K. Kenwood file May 2006 \\
\hline San Dieguito River & SDSADI & 2004 & CA & K. Kenwood file Sept 2005 \\
\hline $\begin{array}{l}\text { Santa Ysabel Creek - } \\
\text { Tim's Canyon }\end{array}$ & SDTICA & 2002 & CA & K. Kenwood file Sept 2005 \\
\hline $\begin{array}{l}\text { San Diego Creek - } \\
\text { Laguna Lakes }\end{array}$ & SGLALA & 2004 & CA & K. Kenwood file Sept 2004 \\
\hline $\begin{array}{l}\text { Los Pinos River - Bear } \\
\text { Dance to } 151\end{array}$ & SJLPBD & 2006 & $\mathrm{CO}$ & T. Ireland email July 2007 \\
\hline $\begin{array}{l}\text { San Juan River - } \\
\text { Shiprock }\end{array}$ & SJSHIP & 1999 & NM & Fitzgerald unpub data \\
\hline $\begin{array}{l}\text { San Luis Rey River - } \\
\text { Agua Caliente Creek }\end{array}$ & SLACCR & 2001 & CA & W. Haas per Kus 2002 table \\
\hline $\begin{array}{l}\text { San Luis Rey River, } \\
\text { Couser Cyn }\end{array}$ & SLCOUS & 2003 & $\mathrm{CA}$ & K. Kenwood file Sept 2005 \\
\hline $\begin{array}{l}\text { San Luis Rey River - } \\
\text { Guajome Lake }\end{array}$ & SLGUAJ & 2006 & CA & Kenwood file may 2007 \\
\hline
\end{tabular}


2006 Southwestern Willow Flycatcher Rangewide Summary

\begin{tabular}{|c|c|c|c|c|}
\hline Site Name & Site Code & Year & State & Reference \\
\hline $\begin{array}{l}\text { San Luis Rey River - } \\
\text { Pilgrim Creek }\end{array}$ & SLPILG & 2006 & CA & Kenwood file May 2007 \\
\hline $\begin{array}{l}\text { De Luz Creek - Camp } \\
\text { Pendleton }\end{array}$ & SMDELU & 2006 & CA & Kenwood file May 2007 \\
\hline $\begin{array}{l}\text { Santa Maria River, } \\
\text { Lower }\end{array}$ & SNSMLO & 2005 & $A Z$ & English et al. 2006 \\
\hline San Mateo Creek & SOSMCR & 2006 & CA & Kenwood file May 2007 \\
\hline $\begin{array}{l}\text { San Pedro River - } \\
\text { Apache Powder Rd }\end{array}$ & SPAPPO & 2004 & $A Z$ & Munzer et al. 2005 \\
\hline $\begin{array}{l}\text { San Pedro River - } \\
\text { Bingham Cienega }\end{array}$ & SPBICl & 2005 & $A Z$ & English et al. 2006 \\
\hline $\begin{array}{l}\text { San Pedro River - } \\
\text { Capgage Wash }\end{array}$ & SPCAWA & 2005 & $A Z$ & English et al. 2006 \\
\hline $\begin{array}{l}\text { San Pedro River - } \\
\text { Hereford Bridge }\end{array}$ & SPHEBR & 2006 & $A Z$ & Graber et al. 2007 \\
\hline $\begin{array}{l}\text { San Pedro River - } \\
\text { Indian Hills }\end{array}$ & SPINHI & 2005 & $A Z$ & English et al. 2006 \\
\hline $\begin{array}{l}\text { San Pedro River - } \\
\text { Malpais Hill }\end{array}$ & SPMAHI & 2005 & $A Z$ & English et al. 2006 \\
\hline $\begin{array}{l}\text { San Pedro River - Soza } \\
\text { Wash }\end{array}$ & SPSOWA & 2003 & $A Z$ & Smith et al. 2004 \\
\hline San Pedro River, SR 90 & SPSR90 & 2006 & $A Z$ & Graber et al. 2007 \\
\hline $\begin{array}{l}\text { Salt River Inflow - Roos } \\
\text { Lk: Lakeshore }\end{array}$ & SRLAKE & 2006 & $A Z$ & Graber et al. 2007 \\
\hline $\begin{array}{l}\text { Salt River - School } \\
\text { House Point N }\end{array}$ & SRSCHN & 2006 & $A Z$ & Graber et al. 2007 \\
\hline $\begin{array}{l}\text { Salt River - School } \\
\text { House Point S }\end{array}$ & SRSCHS & 2006 & $A Z$ & Graber et al. 2007 \\
\hline $\begin{array}{l}\text { Santa Clara River - } \\
\text { Arco/Four Corners }\end{array}$ & STARCO & 2005 & CA & K. Kenwood file May 2006 \\
\hline $\begin{array}{l}\text { Santa Clara River - } \\
\text { Fillmore Fish Hatch }\end{array}$ & STFILL & 2002 & CA & K. Kenwood file Sept 2005 \\
\hline $\begin{array}{l}\text { Santa Clara River - } \\
\text { Saticoy }\end{array}$ & STSATI & 2003 & CA & K. Kenwood file Sept 2005 \\
\hline $\begin{array}{l}\text { Santa Clara River - San } \\
\text { Francisquito Creek }\end{array}$ & STSFCR & 2001 & CA & K. Kenwood file May 2006 \\
\hline $\begin{array}{l}\text { Santa Clara River - } \\
\text { Soledad Canyon }\end{array}$ & STSOCA & 2004 & CA & K. Kenwood file Sept 2005 \\
\hline $\begin{array}{l}\text { Santa Clara River - } \\
\text { Upper Piru Creek }\end{array}$ & STUPPI & 2006 & CA & Kenwood file May 2007 \\
\hline $\begin{array}{l}\text { San Juan Creek - } \\
\text { Canada Gobernadora }\end{array}$ & SUCAGO & 2004 & CA & K. Kenwood file Sept 2005 \\
\hline $\begin{array}{l}\text { San Juan Creek - La } \\
\text { Novia Bridge }\end{array}$ & SUNOBR & 2005 & CA & K. Kenwood file May 2006 \\
\hline Sweetwater Reservoir & SWSWRE & 2006 & CA & Kenwood file May 2007 \\
\hline $\begin{array}{l}\text { Santa Ynez River - } \\
\text { Gibralter }\end{array}$ & SYGIBR & 2002 & CA & K. Kenwood file Sept 2005 \\
\hline
\end{tabular}


2006 Southwestern Willow Flycatcher Rangewide Summary

\begin{tabular}{|c|c|c|c|c|}
\hline Site Name & Site Code & Year & State & Reference \\
\hline $\begin{array}{l}\text { Santa Ynez River - } \\
\text { Lompoc }\end{array}$ & SYLOMP & 2003 & CA & Kenwood Table 04/2005 \\
\hline $\begin{array}{l}\text { Santa Cruz River - } \\
\text { Cienega Creek }\end{array}$ & SZCICR & 2006 & $A Z$ & Graber et al. 2007 \\
\hline $\begin{array}{l}\text { Temecula Creek - } \\
\text { Aguanga }\end{array}$ & TEAGUA & 2001 & CA & K. Kenwood file Sept 2005 \\
\hline $\begin{array}{l}\text { Verde River - Camp } \\
\text { Verde }\end{array}$ & VECAVE & 2005 & $A Z$ & English et al. 2006 \\
\hline Verde River - Davenport & VEDAWA & 2006 & $A Z$ & Graber et al. 2007 \\
\hline Verde River, Ister Flat & VEISTE & 2006 & $A Z$ & Graber et al. 2007 \\
\hline $\begin{array}{l}\text { Verde River - Tavasci } \\
\text { Marsh }\end{array}$ & VETAVA & 1999 & $A Z$ & Paradzick et al. 2000 \\
\hline $\begin{array}{l}\text { Verde River - Tuzigoot } \\
\text { Bridge }\end{array}$ & VETUZI & 2006 & $A Z$ & Graber et al. 2007 \\
\hline Virgin River - Littlefield & VILITT & 2006 & $A Z$ & Graber et al. 2007 \\
\hline $\begin{array}{l}\text { Muddy River - Moapa } \\
\text { Valley }\end{array}$ & VIMUMV & 2006 & NV & Klinger and Furtek 2007 \\
\hline
\end{tabular}

